\title{
Quantifying Anthropogenic Carbon Inventory Changes in the Pacific Sector of the Southern Ocean
}

Nancy L. Williams a, b*, Richard A. Feely ${ }^{\mathrm{b}}$, Christopher L. Sabine ${ }^{\mathrm{b}}$, Andrew G. Dickson ${ }^{c}$, James H. Swift ${ }^{\mathrm{c}}$, Lynne D. Talley ${ }^{\mathrm{c}}$, Joellen L. Russell ${ }^{\mathrm{d}}$

a School of Oceanography, University of Washington, Box 357940, Seattle, WA 981957940, USA

${ }^{\mathrm{b}}$ Pacific Marine Environmental Laboratory, National Oceanic and Atmospheric Administration, 7600 Sand Point Way NE, Seattle, WA 98115-6349, USA.

${ }^{c}$ Scripps Institution of Oceanography, University of California San Diego, 9500 Gilman Drive, La Jolla, CA 92093, USA

${ }^{\mathrm{d}}$ Department of Geosciences, University of Arizona, $1040 \mathrm{E} 4^{\text {th }}$ Street, Tucson, AZ 85721, USA

*Corresponding author.

E-mail addresses: Nancy.Williams@ oregonstate.edu (N.L. Williams), Richard.A.Feely@noaa.gov (R.A. Feely), Chris.Sabine@ noaa.gov (C.L. Sabine), adickson@ucsd.edu (A.G. Dickson), jswift@ucsd.edu (J.H. Swift), 1 talley@ucsd.edu (L.D. Talley), jrussell@email.arizona.edu (J.L. Russell) 


\section{Abstract}

The Southern Ocean plays a major role in mediating the uptake, transport, and long-term storage of anthropogenic carbon dioxide $\left(\mathrm{CO}_{2}\right)$ into the deep ocean. Examining the magnitude and spatial distribution of this oceanic carbon uptake is critical to understanding how the earth's carbon system will react to continued increases in this greenhouse gas. Here, we use the extended multiple linear regression technique to quantify the total and anthropogenic change in dissolved inorganic carbon (DIC) along the S04P and P16S CLIVAR/U.S. Global Ocean Carbon and Repeat Hydrography Program lines south of $67^{\circ} \mathrm{S}$ in the Pacific sector of the Southern Ocean between 1992 and 2011 using discrete bottle measurements from repeat occupations. Along the S04P section, which is located in the seasonal sea ice zone south of the Antarctic Circumpolar Current in the Pacific, the anthropogenic component of the DIC increase from 1992 to 2011 is mostly found in the Antarctic Surface Water (AASW, upper $100 \mathrm{~m}$ ), while the increase in DIC below the mixed layer in the Circumpolar Deep Water can be primarily attributed to either a slowdown in circulation or decreased ventilation of deeper, high $\mathrm{CO}_{2}$ waters. In the AASW we calculate an anthropogenic increase in DIC of $12-18 \mu \mathrm{mol} \mathrm{kg}-1$ and an average storage rate of anthropogenic $\mathrm{CO}_{2}$ of $0.10 \pm 0.02 \mathrm{~mol} \mathrm{~m}^{-2} \mathrm{yr}^{-1}$ for this region compared to a global average of $0.5 \pm 0.2 \mathrm{~mol} \mathrm{~m}^{-2} \mathrm{yr}^{-1}$. In surface waters this anthropogenic $\mathrm{CO}_{2}$ uptake results in an average $\mathrm{pH}$ decrease of $0.0022 \pm 0.0004 \mathrm{pH}$ units $\mathrm{yr}^{-1}$, a $0.47 \pm 0.10 \% \mathrm{yr}^{-1}$ decrease in the saturation state of aragonite $\left(\Omega_{\text {Aragonite }}\right)$ and a $2.0 \pm 0.7 \mathrm{~m} \mathrm{yr}^{-1}$ shoaling of the aragonite saturation horizons (calculated for the $\Omega_{\text {Aragonite }}=1.3$ contour).

\section{Introduction}

Since the beginning of the industrial era, atmospheric concentrations of carbon dioxide $\left(\mathrm{CO}_{2}\right)$ have risen from approximately $280 \mathrm{ppm}$ to over $400 \mathrm{ppm}$ due to fossil fuel burning, cement production, and land-use changes by humans (Rhein et al., 2013; Tans, 2009). This atmospheric increase accounts for only $44 \%$ of the total anthropogenic carbon $\left(\mathrm{C}_{\mathrm{Anth}}\right)$ that has been released because the terrestrial biosphere and the surface ocean absorb the remaining 56\% (Le Quéré et al., 2014). The surface ocean currently absorbs about one quarter of the total

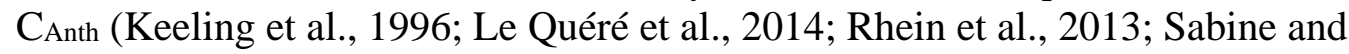
Feely, 2007; Sabine et al., 2004d; Sarmiento and Gruber, 2002; Sarmiento, 1992; Siegenthaler and Sarmiento, 1993); however, this uptake is not spatially uniform and varies based on ocean circulation, solubility differences, air-sea exchange, and water-mass properties. The Southern Ocean, in particular, plays a key role in the oceanic uptake of $\mathrm{C}_{\text {Anth }}$ and, as a result, has gained increased interest in recent years. Studies have shown that the Southern Ocean (south of $50^{\circ} \mathrm{S}$ ) accounts for approximately $30-40 \%$ of the global oceanic CAnth uptake (Khatiwala et al., 2009; Sabine and Feely, 2007), while its waters store only about $9 \%$ of the global ocean's CAnth (Sabine et al., 2004a). This difference between uptake and storage is accounted for by large-scale northward transport of $\mathrm{C}_{\text {Anth-enriched surface }}$ waters out of the Southern Ocean and into the interior of the subtropical oceans (Caldeira, 2000; Gruber, 1998; Hoppema et al., 2001; Sabine et al., 1999). 
The ability of the Southern Ocean to continue to take up $\mathrm{C}_{\text {Anth }}$ is dependent on factors like mixed-layer depth, surface currents, wind stress, subduction rates, and eddy fluxes that may be sensitive to changes in climate (Ito et al., 2010; Sallée et al., 2012). Researchers often use model projections to analyze these potential changes, but the Southern Ocean is a location where models and observations tend to deviate considerably and detailed comparisons are necessary to bridge this gap (Hoppema et al., 2001; Khatiwala et al., 2013; Lo Monaco, 2005; Rusell et al., 2006; Takahashi et al., 2012). Because the Southern Ocean is known to play a large role in global $\mathrm{C}_{\text {Anth }}$ uptake, continued measurement-based and modeling studies of this region are necessary to further our understanding of the global oceanic carbon sink.

While it is possible to measure dissolved inorganic carbon concentrations (DIC) in the ocean, it is not possible to measure $\mathrm{C}_{\text {Anth }}$ directly. The fractional change in the amount of dissolved inorganic carbon in the oceans from preindustrial times to present is less than $1 \%$ and decadal changes are even less. Several approaches have been developed to calculate $\mathrm{C}_{\text {Anth }}$ inventories: databased back-calculation methods such as $C^{*}, \Delta C^{*}$, multiple linear regression (MLR), and $\delta^{13} \mathrm{C}$ (Brewer, 1978; Chen and Millero, 1979; Chen, 1994; Goyet et al., 1999; Gruber et al., 1996; Gruber, 1998; Lee et al., 2003; Lo Monaco, 2005; Pérez et al., 2002; Quay et al., 1992; Sabine et al., 2004b, 1999, 2002; Touratier et al., 2007; Wallace, 1995), tracer-based approaches (Hall et al., 2004, 2002; Waugh et al., 2004), and model-based estimates (Ito et al., 2010; Khatiwala et al., 2013; McNeil et al., 2003; Orr, 2004; Pardo et al., 2014). Some approaches have also been developed to quantify $\mathrm{C}_{\text {Anth }}$ inventory changes on decadal time scales (Friis et al., 2005; Peng et al., 1998; Quay et al., 2003; Tanhua et al., 2007; Wanninkhof et al., 2010). A review of many of these methods can be found in Sabine and Tanhua (2010). While these methods show good agreement in many oceanic regions, the estimation of $\mathrm{C}_{\text {Anth }}$ storage in the Pacific Sector of the Southern Ocean has proven to be more challenging because high-quality carbon observations in this region are limited. Chen $(1994,1987,1982)$ reports on the distribution of $\mathrm{C}_{\text {Anth }}$ in this region using the DIC- measurement-based backcalculation technique and the only DIC-measurement-based decadal $\mathrm{C}_{\text {Anth }}$ inventory change calculation in this region to date is from Sabine et al. (2008) which reports $\mathrm{C}_{\text {Anth }}$ inventory changes along $150^{\circ} \mathrm{W}$ on the meridional P16S hydrographic line between 1991/92 (WOCE Hydrographic Program/JGOFS) and 2005 (CLIVAR).

The ongoing CLIVAR/U.S. Global Ocean Carbon and Repeat Hydrography Program aims to help fill in the gaps in the ocean carbon puzzle by reoccupying 19 hydrographic lines from the earlier WOCE/JGOFS survey on decadal timescales (http://ushydro.ucsd.edu/). Here we present results from a subset of Southern Pacific Ocean WOCE/JGOFS and CLIVAR/U.S. Global Ocean Carbon and Repeat Hydrography Program cruises and calculate changes in the carbon system between 1992 and 2011 based on these observations.

\section{Study region}

All stations used for this study are part of the S04P and P16S

hydrographic lines (see Fig. 1 for map of stations). The stations are located south 
of the Polar Front of the Antarctic Circumpolar Current (ACC) within the Seasonal Sea Ice Zone (SSIZ) and span the entire width of the Pacific sector of the Southern Ocean. The SSIZ is defined as the area south of $62^{\circ} \mathrm{S}$ that experiences a seasonal cycle of sea ice coverage and melt (Popp et al., 1999). The zonal S04P line along $67^{\circ} \mathrm{S}$ was occupied in austral fall of 1992 and 2011 , and the meridional P16S line along $150^{\circ} \mathrm{W}$ was occupied in austral fall 2005 and partially again in austral fall 2011.

The SSIZ is located within the Polar Zone (PZ) south of the eastward flowing ACC and is a region where the surface layer, Antarctic Surface Water (AASW), is extremely cold $\left(\theta<-1.8^{\circ} \mathrm{C}\right)$ and relatively fresh $(\mathrm{S}<33.4)$ due to heat loss to the atmosphere and the addition of freshwater from melting seasonal sea ice. In the austral summer months the upper $\sim 50 \mathrm{~m}$ of the AASW layer warms due to seasonal heating and caps the waters beneath (Dong et al., 2008). The prevailing winds in this region are Westerlies, which export AASW water northward via Ekman transport. Low-oxygen Circumpolar Deep Waters (CDW) flow southward and to the surface to replace this exported AASW by means of Ekman pumping, creating what is known as the diabatic Deacon cell (Callahan, 1972; Speer et al., 2000). As this cool and relatively fresh AASW flows north across the ACC it meets warmer, less dense surface waters and joins the Subantarctic Mode Water (Speer et al., 2000). A portion subducts in the Drake Passage region along the $\gamma^{\mathrm{n}} \approx 27.2 \mathrm{~kg} \mathrm{~m}^{-3}$ neutral density contour, forming Antarctic Intermediate Water (AAIW; Naveira Garabato et al., 2009), which is the subsurface salinity minimum throughout much of the world's ocean basins (e.g. Talley et al., 2011). The remainder of the water column in the SSIZ is filled with upwelling CDW and the very dense bottom layers contain Antarctic Bottom Waters (AABW; Orsi et al., 1999). See Fig. 2 for a schematic of the zonallyaveraged circulation.

The S04P 2011 and P16S 2011 potential temperature $(\theta)$, salinity, and DIC sections shown in Fig. 3 reflect the large-scale circulation in the Pacific sector of the SSIZ. Refer to the WOCE Atlas Volumes 1 and 2 for sections of the earlier S04P 1992 and P16S 2005 occupations (Orsi and Whitworth, 2005; Talley, 2007). The cool and fresh cap of AASW formed by freshwater release from the melting of seasonal sea ice and cooling by strong westerly winds covers the surface of the entire S04P and P16S transects. The S04P transect is divided into two major regimes an approximately $150^{\circ} \mathrm{W}$. The region to the east of $150^{\circ} \mathrm{W}$ is dominated by the eastward-flowing ACC which dips southward close to the Antarctic continent and then back northward as it follows the shelf in the Bellingshausen Sea. In the clockwise Ross Gyre to the west of $150^{\circ} \mathrm{W}$ the eastward-flowing ACC dominates the northern edge of the gyre, while a westward return flow prevails closer to the continental shelf. This circulation is also clearly discernable in dynamic height and the transport streamfunction (Orsi et al., 1995). In both regimes a relatively warm $\left(\sim 2^{\circ} \mathrm{C}\right)$ and low-oxygen core of Upper Circumpolar Deep Water (UCDW) fills the upper 200-500 $\mathrm{m}$ of the water column, and below that lies Lower Circumpolar Deep Water (LCDW), which is marked by a salinity maximum (Callahan, 1972). The warm UCDW core is less defined in the Ross Gyre to the west, which is instead filled mostly by LCDW. 
West of $172^{\circ} \mathrm{E}$, where the S04P line turns southwest and moves up the continental slope toward Cape Adare, is a region of AABW formation characterized by cool, relatively fresh, and extremely dense $\left(\gamma^{\mathrm{n}}>28.27 \mathrm{~kg} \mathrm{~m}^{-3}\right)$ water flowing down the shelf to the bottom of the basin (Swift and Orsi, 2012). AABW formation is seasonal and sporadic, and therefore the relatively small volumes of AABW produced are quickly mixed with LCDW. This mixing process makes the dividing line between AABW and LCDW difficult to define in this region, although the presence of $\mathrm{AABW}$ can be confirmed by the decrease in salinity near the ocean floor (Orsi et al., 1999).

The P16S portion of this transect is situated in the eastern portion of the Ross Gyre and shows the same general water mass features as the S04P line. Moving southward along P16S toward the Antarctic continent the AASW layer thickens due to increased convective cooling. Only stations between $67^{\circ} \mathrm{S}$ and $71^{\circ} \mathrm{S}$ were used for this study due to the limited poleward sampling in the 2005 occupation.

\section{Data analysis}

\section{Analytical methods}

As part of the continuing CLIVAR/U.S. Global Ocean Carbon and Repeat Hydrography Program, high-quality carbon system, oxygen, nutrient, tracer, and other hydrographic observations were made along the S04P and P16S lines in the Pacific basin of the Southern Ocean in February-April 2011 (Swift and Orsi, 2011). Here we will use observations made during the WOCE/JGOFS program along S04P during the same season in 1992 (Beaupre et al., 2005) and along P16S from austral fall of 2005 as part of the CLIVAR/U.S. Global Ocean Carbon and Repeat Hydrography Program (Sloyan and Swift, 2009) to look for decadal changes in water-mass properties.

For all three occupations used for this study, DIC measurements were made using the coulometric titration method (Chipman et al., 1997; DOE, 1994; Feely et al., 2009b; Johnson et al., 1987, 1985, 1993; Sabine et al., 2012). Total alkalinity (TA) measurements were made in 2005 and 2011 using an open-cell, two-stage, potentiometric titration procedure (Dickson et al., 2003, 2007; Feely et al., 2009b). During the 1992 S04P occupation, total alkalinity was not measured directly, however water column $\mathrm{pCO}_{2}$ (partial pressure of $\mathrm{CO}_{2}$ ) measurements were made at $4^{\circ} \mathrm{C}$ using a fully-automated equilibrator-gas chromatograph system (Chipman et al., 1997, 1993). Certified reference materials (CRMs) were used to assure the quality of the shipboard measurements (Dickson et al., 2003; Dickson, 2010, 1990a). See Table 1 for a summary of carbon measurements used for this study. All data are available online from the CLIVAR and Carbon Hydrographic Data Office (http://cchdo.ucsd.edu) and from the Carbon Dioxide Information Analysis Center (http://cdiac.ornl.gov/oceans/).

\section{Crossover analysis}

To check the measurement consistency between data sets we performed a crossover analysis of the 2011 measurements with measurements from earlier occupations in the same locations using the MATLAB $2^{\text {nd }} \mathrm{QC}$ toolbox developed by Tanhua (2010). The MATLAB $2^{\text {nd }}$ QC toolbox references the GLODAP 
(Key et al., 2004; Sabine et al., 2004c) and CARINA (Key et al., 2010; Tanhua et al., 2010) databases to objectively assess differences in deep-water values (depths 1500-3000 m) along $\sigma_{4}$ density surfaces where properties are not expected to change over the 19-year study period. This comparison was performed for all carbon system parameters as well as all other physical and chemical parameters used in this analysis. No significant differences were found in deep waters between occupations and therefore no corrections were made to the data sets (see Supplementary Material).

\section{Preliminary DIC change estimate}

To assess measured changes in DIC, we performed a direct subtraction of gridded measured DIC values as a function of location. This subtraction, shown in Fig. 4(a), gives patchy results in the upper water column where seasonal and interannual variability, large-scale movement of water masses, and isopycnal heave play large roles in controlling DIC. The $\sim 45 \mu \mathrm{mol} \mathrm{kg}{ }^{-1}$ DIC change observed in the upper $200 \mathrm{~m}$ of S04P near $140^{\circ} \mathrm{W}$, for example, is much larger than the expected anthropogenic change and is likely the result of a slight lateral movement of the front between the Ross Gyre and the ACC Loop Gyre between the 1992 and 2011 occupations, which can be observed in the temperature and salinity data as well. Also, the DIC change observed from the surface down to the ocean floor between $80^{\circ} \mathrm{W}$ and the Antarctic Peninsula in the easternmost part of the S04P transect is likely an artifact of a latitudinal difference in location of the stations between the 1992 and 2011 S04P occupations.

\section{AOU Changes}

When examining changes in DIC it is also important to estimate Apparent Oxygen Utilization (AOU) changes. AOU is a function of the amount of respiration and decay of organic matter that has occurred in a parcel of water since it last was in contact with the atmosphere. At the surface, where the measured oxygen values are approximately equal to saturation values, the AOU is zero. As the surface water mixes downward into the ocean interior it loses contact with the atmosphere, AOU increases as oxygen is consumed during respiration by marine organisms, and DIC also increases due to the release of $\mathrm{CO}_{2}$ during these respiration processes. As a result, AOU generally correlates well with water-mass age and increases with depth to a maximum around 300-1000 $\mathrm{m}$ and then begins to decrease slightly in LCDW and AABW, which have been more recently ventilated than the overlying UCDW. Figure 4(b) shows a plot of the measured change in AOU along the S04P and P16S lines. At the surface, where waters are saturated with respect to oxygen during all occupations, the measured AOU change is small. At 50 to $500 \mathrm{~m}$ depth, we observe changes in AOU between occupations of up to $70 \mu \mathrm{mol} / \mathrm{kg}$ along S04P, and above $100 \mu \mathrm{mol} / \mathrm{kg}$ along P16S. Like the direct subtraction of DIC values shown in Fig. 4(a), the direct subtraction of AOU values is not corrected for changes in the location of fronts and isopycnal heave. Changes in observed AOU over time can be an indication that there has either been a change in the flux of organic matter into a water mass or a change in circulation which also has implications for the observed change in carbon.

\section{eMLR method}


In an attempt to remove seasonal and interannual biases, changes in the location of major fronts, and isopycnal heave, and to calculate a more realistic change in DIC, we used a variation of the extended multiple linear regression (eMLR) method developed by Friis et al. (2005). We employed the eMLR method along five neutral density $\left(\gamma^{\mathrm{n}}\right)$ layers, similar to the eMLRdens method used by Wanninkhof et al. (2010). We chose the five neutral $\gamma^{\mathrm{n}}$ layers to represent the major water masses that occupy this region (Table 2).

The eMLR and the previously developed MLR methods are empirical approaches that rely on the robust correlation of changes in DIC with changes in other physical and chemical parameters throughout a large section of the ocean, and account for seasonal and interannual variability between data sets. The eMLR method minimizes the errors introduced by independent variables to the $\Delta \mathrm{C}_{\text {Anth }}$ calculation as compared to the previously developed MLR method (Friis et al., 2005; Wallace, 1995). The measured DIC data for each occupation are fit independently using a MLR to a series of independent predictor variables; in this case, potential temperature $(\theta)$, salinity $(S)$, neutral density $\left(\gamma^{n}\right)$, silicate $(S i)$, and phosphate $(P)$. The same set of predictor variables is fit separately to each of the five density layers for both occupations, resulting in 10 independent sets of MLR coefficients per hydrographic line. The change (or difference) in the resultant MLR coefficients between the two occupations is then used in conjunction with the hydrographic data from the most recent occupation to calculate $\Delta \mathrm{C}_{\text {Total }}$, the change in DIC between the two cruises. Equations (1) through (3) illustrate the eMLR fit method:

$$
\begin{aligned}
& D I C_{: 2}=A+B\left(S_{t 2}\right)+C\left(\theta_{t 2}\right)+D\left(\gamma_{r_{12}}\right)+E\left(P_{! 2}\right)+f\left(S i_{62}\right) \\
& D J C_{i 1}=a+b\left(S_{i 2}\right)+c\left(\theta_{i 1}\right)+d\left(\gamma_{r_{1}}\right)+c\left(P_{t 1}\right)+f\left(S i_{i 1}\right) \\
& \Delta c_{\text {rotal }}=(A-a)+(B-b)\left(S_{i 2}\right)+(C-c)\left(\theta_{i 2}\right)+(D-d)\left(\gamma_{i i 2}\right)+ \\
& (E-c)\left(P_{i 2}\right)+(F-f)\left(S i_{t 2}\right)
\end{aligned}
$$

The coefficients of the MLR fits for DIC are shown in Table 3. The standard errors in $\Delta$ C Total associated with the fits range from \pm 0.6 to $\pm 3.6 \mu \mathrm{mol}$ $\mathrm{kg}^{-1}$. Errors in the individual measurements used for the fits are inherently canceled out by the subtraction of the MLR fit coefficients. Plots of MLRpredicted versus measured DIC are shown in the Supplemental Material along with maps of the residuals of the fits. Note that stations located west of $172^{\circ} \mathrm{E}$ were not used for the eMLR fit because this is a region where short-timescale processes such as surface freezing, nonlinear mixing, and air-sea gas exchange act to drive AABW formation (Jacobs et al., 1970; Orsi et al., 1999). As a result, the entire water column acts like a deep mixed layer in this region and the eMLR method cannot be applied. In addition, we did not use data from south of $71^{\circ} \mathrm{S}$ along the P16S line because this was the southernmost extent of the 2005 dataset. Mixed layer calculation

In the seasonally affected mixed layer where the eMLR method produces the largest errors we used the known atmospheric change in $\mathrm{pCO}_{2}$ (GLOBALVIEW-CO 2,2013 ) between the two occupations to estimate a change in DIC using CO2SYS (Lewis and Wallace, 1998; van Heuven et al., 2011). This method assumes that despite the large seasonal and spatial variations in surface $\mathrm{pCO}_{2}$, the average surface $\mathrm{pCO}_{2}$ south of the Polar Front (PF) of the ACC 
has increased proportionally to the average atmospheric increase $\left(\sim 1.8 \mu \mathrm{atm} \mathrm{yr}^{-1}\right)$ during the study period (Takahashi et al., 2009; Yoshikawa-Inoue and Ishii, 2005). This assumption that the surface ocean mixed layer is in equilibrium or, at least, a constant disequilibrium with the atmosphere during all occupations, which could cause a 5-10\% overestimation in $\Delta \mathrm{C}_{\text {Anth }}$ (Hall et al., 2004). We calculated the mixed layer depth to be on average $\sim 50 \mathrm{~m}$ using the potential density and potential temperature gradients as described by Dong et al. (2008). To calculate the mixed layer $\Delta \mathrm{C}_{\text {Total }}$ we calculate the pre- $\Delta \mathrm{C}_{\text {Anth }} \mathrm{DIC}$ using CO2SYS (Lewis and Wallace, 1998; van Heuven et al., 2011) using the most recently measured TA and surface $\mathrm{pCO}_{2}$ values minus the atmospheric $\mathrm{pCO}_{2}$ increase during that time period as shown in Eq. (4). We use constants of Lueker et al. (2000) and Dickson (1990) for all CO2SYS calculations in this study. In Eq. (5), we subtract the pre- $\Delta \mathrm{C}_{\text {Anth }}$ DIC value from the measured DIC of the most recent occupation and the difference is the $\Delta \mathrm{C}_{\text {Total }}$ for the mixed layer. We then combine the $\Delta \mathrm{C}_{\text {Total }}$ calculated using the eMLR method (for depths $>50 \mathrm{~m}$ ) and the $\Delta \mathrm{C}_{\text {Total }}$ calculated in the mixed layer (for depths $<50 \mathrm{~m}$ ) using the atmospheric change to obtain a full water column $\Delta \mathrm{C}_{\text {Total. }}$ One assumption that is inherent to the eMLR method is that TA has not changed between the two occupations, and as TA was not measured directly on the 1991-1992 occupations we cannot check the validity of this assumption.

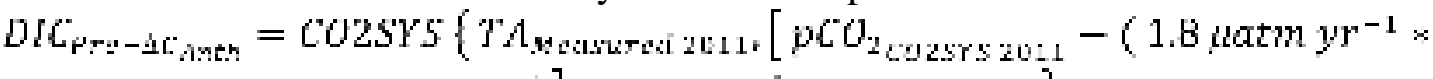

$$
\begin{aligned}
& \text { yrs )], meesured T,S, Pressure\} }
\end{aligned}
$$

[4]

\section{Results}

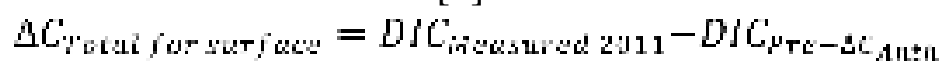

\section{DIC changes}

The results of the total carbon change $\left(\Delta C_{\text {Total }}\right)$ eMLR are shown in Fig. 5a. The $\Delta \mathrm{C}_{\text {Total }}$ ranges from $2-18 \mu \mathrm{mol} \mathrm{kg}$-1 along the S04P line between 1992 and 2011 and extends from the surface down to a depth of $1000 \mathrm{~m}$ in the Ross Gyre in the west and down to around 2200m in the ACC Loop Gyre in the east. The $\Delta C_{\text {Total }}$ signal roughly follows isopycnals, which are deeper in the ACC Loop Gyre in the east than in the Ross Gyre in the west. The estimated DIC change corresponding to the measured atmospheric change in the mixed layer along S04P between 1992 and 2011 is $12-18 \mu \mathrm{mol} \mathrm{kg}{ }^{-1}$. Similarly, the $\Delta \mathrm{C}_{\text {Total }}$ in the mixed layer along the P16S line corresponding to the measured atmospheric change between 2005 and 2011 is $3-5 \mu \mathrm{mol} \mathrm{kg}{ }^{-1}$. Measurable changes in $\Delta \mathrm{C}_{\text {Total }}$ extend from the surface down to $450 \mathrm{~m}$ along P16S between 2005 and 2011, with deeper penetration in the southernmost stations, again due to deepening isopycnals towards the south. The small changes observed in the AABW and 'new' AABW layers will be addressed in the discussion.

\section{AOU change correction}

The eMLR method is sensitive to changes in AOU due to the dependence of DIC concentrations on organic matter respiration (Sabine et al., 2008; Wanninkhof et al., 2010). In order to calculate the portion of the $\Delta C_{\text {Total }}$ that can be associated with a change in AOU, $\Delta \mathrm{C}_{\mathrm{AOU}}$, we use a method similar to Sabine et al. (2008) and fit AOU separately from DIC using a second set of MLRs and the 
same set of five predictor variables between $50 \mathrm{~m}$ and the seafloor. Note that oxygen was purposely not used for the initial DIC MLR fits so that AOU could be used to evaluate the contribution of circulation and remineralization changes. The $\triangle \mathrm{AOU}$ is obtained in the same way as the $\Delta \mathrm{C}_{\text {Total: }}$ by taking the difference between AOU MLR fit coefficients for two occupations, and multiplying by the measured data for the most recent occupation. The fitted coefficients for the AOU MLR fits are shown in Table 4. The standard errors associated with the AOU MLR fits range from \pm 0.01 to $\pm 8.5 \mu \mathrm{mol} \mathrm{kg}{ }^{-1} \mathrm{O}_{2}$. Because the surface water is saturated with respect to oxygen, the surface $\triangle \mathrm{AOU}$ was set to zero and the $\triangle \mathrm{AOU}$ values for the mixed layer were linearly interpolated between the surface and the eMLR fit result at $50 \mathrm{~m}$.

Carbon is released and oxygen consumed at a known stoichiometric ratio during the decay of organic matter, which has been empirically calculated as 117 $\mathrm{CO}_{2}$ :- $170 \mathrm{O}_{2}$ (Anderson and Sarmiento, 1994). We obtained the $\Delta \mathrm{C}_{\mathrm{AOU}}$ by multiplying the $\triangle \mathrm{AOU}$ from the eMLR result by $117 / 170$ as shown in Eq. (6). We then subtract this $\Delta \mathrm{C}_{\mathrm{AOU}}$ from the $\Delta \mathrm{C}_{\text {Total }}$ to obtain the anthropogenic

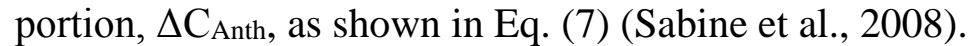

$$
\begin{gathered}
\Delta C_{A O U}=\Delta O U \leqslant\left(\frac{117}{171}\right) \\
\Delta C_{A n t h}=\Delta C_{\text {Jot }}-\Delta C_{A O U}
\end{gathered}
$$

The $\Delta \mathrm{C}_{\mathrm{AOU}}$ is shown in Fig. $5 \mathrm{~b}$ and is on the order of $\sim 0-10 \mu \mathrm{mol} \mathrm{kg} \mathrm{k}^{-1}$ along S04P between 1992 and 2011 in CDW at depths of 150 to $2200 \mathrm{~m}$. The $\triangle \mathrm{C}_{\mathrm{AOU}}$ along $\mathrm{P} 16 \mathrm{~S}$ is $0-5 \mu \mathrm{mol} \mathrm{\textrm {kg } ^ { - 1 }}$ at depths between 150 and $400 \mathrm{~m}$. The $\Delta \mathrm{C}_{\mathrm{AOU}}$ signal roughly follows isopycnals and therefore it is much more prominent in the ACC Loop Gyre in the eastern half of the S04P transect and is less prominent in the Ross Gyre to the west and along the P16S transect.

The changes in AOU obtained from the eMLR fit account for approximately $0-10 \mu \mathrm{mol} \mathrm{kg} \mathrm{kg}^{-1}$ of the $\Delta \mathrm{C}_{\text {Total }}$ between 1992 and 2011 at intermediate depths and up to $75 \%$ of the column inventory of $\Delta \mathrm{C}_{\mathrm{Total}}$, and imply that these waters have experienced an increase in respiration either due to an increase in the flux of organic matter or a slowdown in circulation. This AOU increase is greatest in the ACC Loop Gyre in the eastern half of the section (east of $150^{\circ} \mathrm{W}$ ), and less in the Ross Gyre in the western half of the section (west of $\left.150^{\circ} \mathrm{W}\right)$. Using these data we are unable to draw a conclusion about the driver behind this AOU change; however, other studies have suggested that changing climate and circulation changes could act to change water mass ages in this region. For example, Waugh et al. (2013) used CFC-12 data along P16S to show an increased apparent age of polar CDW. Matear et al. (2000) also both observed and modeled a subsurface decrease in oxygen concentrations (increased AOU) around $350 \mathrm{~m}$ depth in the Southern Ocean and have attributed the decrease to a reduction in convective ventilation owing to shallower winter mixed layers and southward shifted Westerlies.

Another explanation for this measured increase in AOU between occupations comes from possible errors inherent in the assumptions that are made to calculate AOU. To calculate AOU, we assume that the water parcel was in equilibrium with the atmosphere and was at $100 \%$ saturation with respect to oxygen before it subducted. In the Southern Ocean in particular, this assumption 
is not always correct, and researchers have shown that undersaturation in AAIW is common and can vary over time (Russell and Dickson, 2003). An

undersaturation during water mass formation due to blockage by sea ice or a short residence time at the surface would result in falsely large AOU calculations. Any overestimations in AOU for either the earlier or later occupation would result in errors in $\Delta \mathrm{C}_{\mathrm{AOU}}$, and, in turn, an error in $\Delta \mathrm{C}_{\mathrm{Anth}}$. The eMLR method decreases the uncertainty due to possible undersaturation/disequilibrium when we take a difference between occupations because we are assuming constant conditions at the surface. For example, if waters in this region were undersaturated with respect to oxygen during the same times and to the same extent each year, then this error in our assumption of saturation would cancel out.

\section{Anthropogenic carbon changes}

After correcting $\Delta \mathrm{C}_{\mathrm{Total}}$ for $\Delta \mathrm{C}_{\mathrm{AOU}}$ using $\mathrm{Eq}$. (7), the 19 -year $\Delta \mathrm{C}_{\text {Anth }}$ shown in Fig. $5 \mathrm{c}$ ranges from $\sim 2$ to $18 \mu \mathrm{mol} \mathrm{kg}{ }^{-1}$ along the S04P transect. The $\triangle \mathrm{C}_{\text {Anth }}$ is mostly isolated to the AASW layer, and penetrates to a depth of $100-150 \mathrm{~m}$ along the entirety of the S04P transect. There is a $\sim 2-4 \mu \mathrm{mol} \mathrm{kg}{ }^{-1}$ increase in $\mathrm{C}_{\text {Anth }}$ observed in the youngest $\mathrm{AABW}$ and a $\sim 2-4 \mu \mathrm{mol} \mathrm{kg} \mathrm{kg}^{-1}$ decrease observed in several stations between 3000 and $4000 \mathrm{~m}$ in the Ross Gyre. These $\sim 2-4 \mu \mathrm{mol} \mathrm{kg}{ }^{-1}$ changes are close to the detection limit of $\Delta \mathrm{C}_{\text {Anth }}$ for these density layers, which is 3.4 and 3.6 for layers 4 and 5, respectively. The detection limit of $\Delta \mathrm{C}_{\text {Anth }}$ varies between each density layer and between P16S and S04P, but can be calculated using the standard errors in the eMLR fits in Tables 3 and 4. Along P16S, the six-year $\Delta \mathrm{C}_{\text {Anth }}$ signal is $\sim 2-8 \mu \mathrm{mol} \mathrm{kg}^{-1}$ in the AASW layer and we also observe a $\sim 4 \mathrm{~mol} \mathrm{~kg}^{-1} \Delta \mathrm{C}_{\text {Anth }}$ around $3400 \mathrm{~m}$ in two of the southernmost stations.

\section{Discussion}

\section{Anthropogenic carbon storage rates}

In order to compare the results of this study with other similar studies we integrate each component of the carbon change over depth and calculate annual rates of change across each hydrographic transect. Figure 6 shows rates of column inventory change of $\Delta \mathrm{C}_{\mathrm{Total}}, \Delta \mathrm{C}_{\mathrm{AOU}}$, and $\Delta \mathrm{C}_{\mathrm{Anth}}$ along each transect based on the column inventory of Figs. 5a, b, and c. We calculate a storage rate of $C_{\text {Anth }}$ of $0.10 \pm 0.02 \mathrm{~mol} \mathrm{~m}^{-2} \mathrm{yr}^{-1}$ along S04P and $0.16 \pm 0.03 \mathrm{~mol} \mathrm{~m}^{-2} \mathrm{yr}^{-1}$ along P16S. The thickness of the AASW layer is relatively uniform across the S04P transect and, as a result, the $\mathrm{C}_{\text {Anth }}$ storage rate is longitudinally uniform as well. The $\mathrm{C}_{\text {Anth }}$ storage rate along the $\mathrm{P} 16 \mathrm{~S}$ transect, however, increases southward from $0.09 \pm 0.03 \mathrm{~mol} \mathrm{~m}^{-2} \mathrm{yr}^{-1}$ at the S04P/P16S crossover point at $67^{\circ} \mathrm{S}$ to a maximum of $0.34 \pm 0.03 \mathrm{~mol} \mathrm{~m}^{-2} \mathrm{yr}^{-1}$ at $71^{\circ} \mathrm{S}$ as the AASW thickens southward, consistent with the findings of Chen (1994, 1987, 1982). Along S04P, AOU changes account for $\sim 65 \%$ of the $\Delta \mathrm{C}_{\text {Total }}$ between 1992 and 2011 and account for $\sim 20 \%$ of the $\Delta \mathrm{C}_{\text {Total }}$ between 2005 and 2011 along P16S. Because most of the carbon change in the UCDW layer can be associated with a change in $\mathrm{AOU}$, the column-integrated $\Delta \mathrm{C}_{\mathrm{Total}}$ and $\Delta \mathrm{C}_{\mathrm{AOU}}$ are larger in the eastern half of the S04P transect where the UCDW layer is thicker than in the western half. The $\mathrm{C}_{\text {Anth }}$ storage rates calculated independently from S04P and P16S agree at the crossover point, but the AOU-related carbon change rate - and therefore the total 
carbon change rate-do not agree within their uncertainties. This disagreement is an indication that the processes acting to change AOU may not be uniform in time between 1992 and 2011 in this region.

The average storage rate of $\mathrm{C}_{\text {Anth }}$ calculated in this study of $0.10 \pm 0.02$ mol C m$~^{-2} \mathrm{yr}^{-1}$ is consistent with the previous storage rate of $0.1 \mathrm{~mol} \mathrm{C} \mathrm{m}^{-2} \mathrm{yr}^{-1}$ obtained by Sabine et al. (2008) using the eMLR method between 1992 and 2005 at the crossover point for S04P and $\mathrm{P} 16 \mathrm{~S}$ at $67^{\circ} \mathrm{S} 150^{\circ} \mathrm{W}$. Table 5 shows the $\mathrm{C}_{\text {Anth }}$ storage rate calculated in this study compared with results from other regions of the ocean. The storage rates measured in this study region south of the $\mathrm{PF}$ are relatively small $\left(0.10 \pm 0.02 \mathrm{~mol} \mathrm{C} \mathrm{m}^{-2} \mathrm{yr}^{-1}\right)$ compared to the global average storage rate of $0.5-0.55 \mathrm{~mol} \mathrm{C} \mathrm{m}^{-2} \mathrm{yr}^{-1}$ (Khatiwala et al., 2009; Sabine et al., 2008). Storage rates are relatively low south of the PF due to ongoing winddriven northward export of $\mathrm{C}_{\text {Anth-rich surface waters from south to north across }}$ the PF of the ACC and the constant upwelling of older waters. In addition, strong summertime surface stratification and winter sea ice coverage prevent mixing of $\mathrm{C}_{\text {Anth }}$ past the depth of the mixed layer on the timescale of this study.

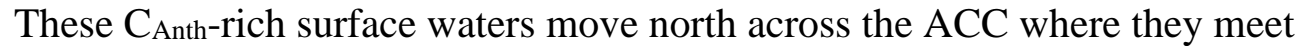
less-dense waters and subduct along the $\gamma^{\mathrm{n}} \approx 27.2 \mathrm{~kg} \mathrm{~m}^{-3}$ neutral density isopycnal to form AAIW, facilitating northward subsurface advection of $\mathrm{C}_{\text {Anth. }}$. Storage rates increase to $0.75 \mathrm{~mol} \mathrm{C} \mathrm{m}^{-2} \mathrm{yr}^{-1}$ moving equatorward into the Pacific Ocean (Sabine et al., 2008) where waters are experiencing both diffusion of $\mathrm{C}_{\text {Anth }}$ from above and advection of $\mathrm{C}_{\text {Anth }}$ into the region from the south at depth.

The results of this study are also consistent with results from a recent total $\mathrm{C}_{\text {Anth }}$ inventory, [Cant], calculated by Pardo et al. (2014) using the $\mathcal{C}_{\mathrm{T}}^{\mathrm{v}}$ method. This approach, which calculates total $\mathrm{C}_{\text {Anth }}$ changes from preindustrial to present, showed that along the S04P line, the overall $\mathrm{C}_{\text {Anth }}$ inventory from preindustrial time to 1994 is 5-7 $\mu \mathrm{mol} \mathrm{kg}^{-1}$ in both CDW and AABW (Pardo et al., 2014). If we extrapolate this inventory to our study, a DIC increase of less than $1 \mu \mathrm{mol}$ $\mathrm{kg}^{-1}$ would be expected in both CDW and AABW for the period between 1992 and 2011. We consider our results to be in agreement with Pardo et al. because we were unable to detect a significant $\Delta \mathrm{C}_{\text {Anth }}$ signal in CDW during our study period and we detected only a small $\left(\sim 3 \mu \mathrm{mol} \mathrm{kg}{ }^{-1}\right)$ change in AABW in a few of the westernmost stations where we find the most recently formed AABW (Swift and Orsi, 2012). Anthropogenic carbon storage is undetectable in CDW throughout this study period likely due to seasonal sea ice coverage and strong surface stratification. In addition, the $\mathrm{C}_{\mathrm{Anth}}$ storage rate is small in $\mathrm{AABW}$ over this study period. It is possible that $\mathrm{AABW}$ does not absorb a significant amount of anthropogenic $\mathrm{CO}_{2}$ before it sinks to depth and/or that $\mathrm{AABW}$ is formed in such small quantities that it quickly mixes with LCDW and the anthropogenic signal is diluted below the detection limit of the eMLR method (Poisson and Chen, 1987).

\section{Changes in surface water $\mathrm{pH}$ and aragonite saturation state}

It has been estimated that the average surface ocean $\mathrm{pH}$ has dropped by about $0.11 \mathrm{pH}$ units since the beginning of industrialization, which equates to approximately a $30 \%$ increase in the hydrogen ion concentration and acidity, and 
a $16 \%$ decrease in the saturation state of aragonite $\left(\Omega_{\text {Aragonite }}\right.$; Feely et al., 2012 , 2009a; Orr, 2011; Orr et al., 2005). This acidification reduces the ocean's ability to store additional carbon, and also has significant negative impacts on the growth of calcifying organisms and on the livelihood of many other organisms that depend on them (Bednaršek et al., 2014, 2012; Doney et al., 2009; Feely et al., 2004). The $\Delta \mathrm{C}_{\text {Anth }}$ results from this study can be used in conjunction with measured alkalinity data to calculate $\mathrm{pH}$ and $\Omega_{\text {Aragonite }}$ changes using CO2SYS (Lewis and Wallace, 1998; van Heuven et al., 2011). The estimated anthropogenic $\mathrm{pH}$ and $\Omega_{\text {Aragonite }}$ changes are shown in Fig. 7.

Anthropogenic carbon uptake along S04P has decreased surface water $\mathrm{pH}$ by $0.042 \pm 0.007 \mathrm{pH}$ units between 1992 and 2011 and by $0.014 \pm 0.006 \mathrm{pH}$ units along P16S between 2005 and 2011. We calculate an overall rate of anthropogenic $\mathrm{pH}$ decrease in surface waters of $0.0022 \pm 0.0004 \mathrm{pH}$ units $\mathrm{yr}^{-1}$ and $0.0024 \pm 0.0009 \mathrm{pH}$ units $\mathrm{yr}^{-1}$ along S04P and P16S, respectively. We calculate an anthropogenic decrease in the surface water $\Omega_{\text {Aragonite }}$ of $0.47 \pm 0.10$ $\% \mathrm{yr}^{-1}$ along S04P and $0.50 \pm 0.20 \% \mathrm{yr}^{-1}$ along P16S, resulting in an average shoaling of the saturation horizons (using $\Omega_{\text {Aragonite }}=1.3$ horizon) of $2.0 \pm 0.7 \mathrm{~m}$ $\mathrm{yr}^{-1}$ throughout the study region. A summary of these results as well as results from previous surface water $\mathrm{pH}$ and $\Omega_{\text {Aragonite }}$ studies is shown in Table 6 . It is important to note that while anthropogenic $\mathrm{pH}$ and $\Omega_{\text {Aragonite }}$ changes are only detected in the mixed layer in this region, $\mathrm{C}_{\text {Anth }}$ penetrates much deeper in areas north of the $\mathrm{PF}$ and $\mathrm{pH}$ and $\Omega_{\text {Aragonite }}$ changes are observed at deeper depths in those regions.

Revelle factors are generally lower in the tropics and subtropics (currently 9) and increase poleward (currently 15) making high-latitude surface waters more sensitive to changes in DIC. Hence when one estimates the $\Delta \mathrm{pCO}_{2}, \Delta \mathrm{pH}$, or $\Delta \Omega_{\text {Aragonite }}$ resulting from a particular amount of uptake of $\mathrm{C}_{\text {Anth }}$ it will be higher for high-latitude waters than for the tropics and subtropics. Surface water anthropogenic $\mathrm{pH}$ and $\Omega_{\text {Aragonite }}$ changes in our study region are among the highest measured globally and the rates are comparable to those observed in other high-latitude surface waters. For example, Midorikawa et al. (2012) measured a pH decrease of $0.0020 \pm 0.0003 \mathrm{pH}$ units $\mathrm{yr}^{-1}$ in the $\mathrm{PZ}$ of the Southern Ocean and Takahashi et al. (2014) calculated a decrease of $0.0015 \pm$ $0.0008 \mathrm{pH}$ units $\mathrm{yr}^{-1}$ in the $\mathrm{PZ}$ of the Drake Passage. In the Iceland and Irminger Seas, researchers have measured a $\mathrm{pH}$ decrease of $0.0023 \pm 0.0003$ (Olafsson et al., 2009) and $0.0026 \pm 0.0006 \mathrm{pH}$ units $\mathrm{yr}^{-1}$ (Bates et al., 2014), respectively, compared to a decrease of $0.0022 \pm 0.0004 \mathrm{pH}$ units $\mathrm{yr}^{-1}$ for the S04P line. Tropical and subtropical regions are experiencing $\mathrm{pH}$ decreases on the order of $0.0017 \mathrm{pH}$ units $\mathrm{yr}^{-1}$ and $\Omega_{\text {Aragonite }}$ saturation horizon shoaling of $1 \pm 0.6 \mathrm{~m} \mathrm{yr}^{-1}$ (Bates et al., 2014; Byrne et al., 2010; Dore et al., 2009; Feely et al., 2012; González-Dávila et al., 2010; Ishii et al., 2011; Midorikawa et al., 2010; Takahashi et al., 2014; Waters et al., 2011), indicating that polar surface waters are acidifying more quickly than tropical and subtropical waters.

\section{Conclusions}

Over the period of 1992 to 2011, south of the Polar Front (PF) in the

Pacific Sector of the Southern Ocean, measurable anthropogenic $\mathrm{CO}_{2}$ storage is 
isolated to the mixed layer and to the most recently formed Antarctic Bottom Water $(\mathrm{AABW})$. Anthropogenic carbon $\left(\mathrm{C}_{\mathrm{Anth}}\right)$ storage rates in this region are small compared to storage rates north of the Antarctic Circumpolar Current (ACC) because of the large-scale transport of $\mathrm{C}_{\text {Anth-rich surface waters northward }}$ across the ACC where they subduct to form Antarctic Intermediate Water (AAIW). Regions north of the PF have higher storage rates because they are experiencing both uptake of $\mathrm{C}_{\text {Anth }}$ from the atmosphere and addition of $\mathrm{C}_{\mathrm{Anth}}$ via advective transport within the AAIW layer at depth. Although $\mathrm{C}_{\text {Anth }}$ storage rates are low in this region, the Southern Ocean is responsible for a large portion of the global $\mathrm{C}_{\text {Anth }}$ storage beneath the thermocline.

We observe an increase in Apparent Oxygen Utilization (AOU) in Circumpolar Deep Water (CDW) over the study period, which may indicate a recent change in circulation in the Pacific sector of the Southern Ocean. This change in circulation may impact the ability of this region to take up $\mathrm{C}_{\mathrm{Anth}}$ in the future.

In addition, the surface waters in this region are acidifying at a faster rate than the tropical and subtropical oceans due to the higher sensitivity of polar waters to $\mathrm{C}_{\text {Anth. }}$. As a result, the surface water saturation state of aragonite ( $\Omega_{\text {Aragonite }}$ ) is decreasing more quickly in this region and these waters will likely become undersaturated sooner than the warmer subtropical and tropical waters to the north.

\section{Acknowledgment}

The National Oceanic and Atmospheric Administration (NOAA) and the National Science Foundation sponsored this work. We specifically acknowledge Joel Levy and David Legler of the NOAA Climate Program Office, and Eric Itsweire and Don Rice of the National Science Foundation for their continued support. We would also like to thank all the officers, crew, and scientists of the WOCE/JGOFS and CLIVAR/U.S. Global Ocean Carbon and Repeat Hydrography Program cruises for providing these valuable data. This is PMEL contribution number 4228. 


\section{References}

Anderson, L.A., Sarmiento, J.L., 1994. Redfield ratios of remineralization determined by nutrient data analysis. Global Biogeochem. Cycles. doi:10.1029/93GB03318

Bates, N., Astor, Y., Church, M., Currie, K., Dore, J., Gonaález-Dávila, M., Lorenzoni, L., Muller-Karger, F., Olafsson, J., Santa-Casiano, M., 2014. A time-series view of changing ocean chemistry due to ocean uptake of anthropogenic $\mathrm{CO}_{2}$ and ocean acidification. Oceanography 27, 126-141. doi:10.5670/oceanog.2014.16

Beaupre, M.-C., Jennings, J.C., Key, R.M., Morozov, E., Schlosser, P., 2005. CRUISE REPORT - WOCE S04P [WWW Document]. URL http://cchdo.ucsd.edu/data/b/c31631/s04pdo.pdf

Bednaršek, N., Feely, R.A., Reum, J.C.P., Peterson, B., Menkel, J., Alin, S.R., Hales, B., 2014. Limacina helicina shell dissolution as an indicator of declining habitat suitability owing to ocean acidification in the California Current Ecosystem. Proc. Biol. Sci. 281, 20140123. doi:10.1098/rspb.2014.0123

Bednaršek, N., Tarling, G.A., Bakker, D.C.E., Fielding, S., Jones, E.M., Venables, H.J., Ward, P., Kuzirian, A., Lézé, B., Feely, R.A., Murphy, E.J., 2012. Extensive dissolution of live pteropods in the Southern Ocean. Nat. Geosci. 5, 881-885. doi:10.1038/ngeo1635

Brewer, P.G., 1978. Direct observation of the oceanic $\mathrm{CO}_{2}$ increase. Geophys. Res. Lett. 5, 997-1000.

Byrne, R.H., Mecking, S., Feely, R.A., Liu, X., 2010. Direct observations of basin-wide acidification of the North Pacific Ocean. Geophys. Res. Lett. 37, L02601. doi:10.1029/2009GL040999

Caldeira, K., 2000. The role of the Southern Ocean in uptake and storage of anthropogenic carbon dioxide. Science 37, 620-622.

doi:10.1126/science.287.5453.620

Callahan, J.E., 1972. The structure and circulation of deep water in the Antarctic. DeepSea Res. doi:10.1016/0011-7471(72)90040-X

Chen, C.-T.A., 1982. On the distribution of anthropogenic $\mathrm{CO}_{2}$ in the Atlantic and Southern oceans. Deep-Sea Res. doi:10.1016/0198-0149(82)90076-0

Chen, C.-T.A., 1987. On the depth of anthropogenic $\mathrm{CO}_{2}$ penetration in the Atlantic and Pacific Oceans. Oceanol. Acta 29, 97-102. 
Chen, C.-T.A., 1994. Some Indications of Excess $\mathrm{CO}_{2}$ Penetration near Cape Adare off the Ross Sea. La mer 32, 167-172.

Chen, C.-T.A., Millero, F.J., 1979. Gradual increase of oceanic $\mathrm{CO}_{2}$. Nature. doi:10.1038/277205a0

Chipman, D.W., Marra, J., Takahashi, T., 1993. Primary production at $47^{\circ} \mathrm{N}$ and $20^{\circ} \mathrm{W}$ in the North Atlantic Ocean: a comparison between the ${ }^{14} \mathrm{C}$ incubation method and the mixed layer carbon budget. Deep Sea Res. Part II Top. Stud. Oceanogr.

doi:10.1016/0967-0645(93)90011-B

Chipman, D.W., Takahashi, T., Rubin, S., Sutherland, S.C., Koshlyakov, M.H., 1997. Carbon Dioxide, Hydrographic, and Chemical Data Obtained During the R/V Akademik Ioffe Cruise in the South Pacific Ocean (WOCE Section S4P, FebruaryApril 1992). Oak Ridge, Tennessee. doi:10.3334/CDIAC/otg.ndp063

Dickson, A.G., 1990a. The oceanic carbon dioxide system: planning for quality data. US JGOFS News 2, 10.

Dickson, A.G., 1990b. Standard potential of the reaction: $\mathrm{AgCl}(\mathrm{s})+1 / 2 \mathrm{H}_{2}(\mathrm{~g})=\mathrm{Ag}(\mathrm{s})+$ $\mathrm{HCl}(\mathrm{aq})$, and the standard acidity constant of the ion $\mathrm{HSO}_{4}{ }^{-}$in synthetic sea water from 273.15 to 318.15 K. J. Chem. Thermodyn. 22, 113-127. doi:10.1016/00219614(90)90074-Z

Dickson, A.G., 2010. Standards for Ocean Measurements. Oceanography 23, 34-47. doi:10.5670/oceanog.2010.22

Dickson, A.G., Afghan, J.D., Anderson, G.C., 2003. Reference materials for oceanic $\mathrm{CO}_{2}$ analysis: a method for the certification of total alkalinity. Mar. Chem. doi:10.1016/S0304-4203(02)00133-0

Dickson, A.G., Sabine, C.L., Christian, J.R., 2007. Guide to Best Practices for Ocean $\mathrm{CO}_{2}$ Measurements. PICES Special Publication 3.

DOE, 1994. Handbook of methods for the analysis of the various parameters of the carbon dioxide system in sea water, 2nd ed. ORNL/CDIAC-74.

Doney, S.C., Fabry, V.J., Feely, R.A., Kleypas, J.A., 2009. Ocean acidification: the other $\mathrm{CO}_{2}$ problem. Ann. Rev. Mar. Sci. 1, 169-192.

doi:10.1146/annurev.marine.010908.163834

Dong, S., Sprintall, J., Gille, S.T., Talley, L., 2008. Southern Ocean mixed-layer depth from Argo float profiles. J. Geophys. Res. 113, 1-12. doi:10.1029/2006JC004051 
Dore, J.E., Lukas, R., Sadler, D.W., Church, M.J., Karl, D.M., 2009. Physical and biogeochemical modulation of ocean acidification in the central North Pacific. Proc. Natl. Acad. Sci. U. S. A. 106, 12235-12240. doi:10.1073/pnas.0906044106

Feely, R.A., Doney, S.C., Cooley, S.R., 2009a. Ocean Acidification: Present Conditions and Future Changes in a High- $\mathrm{CO}_{2}$ World. Oceanography. doi:10.5670/oceanog.2009.95

Feely, R.A., Sabine, C.L., Byrne, R.H., Millero, F.J., Dickson, A.G., Wanninkhof, R., Murata, A., Miller, L.A., Greeley, D., 2012. Decadal changes in the aragonite and calcite saturation state of the Pacific Ocean. Global Biogeochem. Cycles 26, 1-15. doi:10.1029/2011GB004157

Feely, R.A., Sabine, C.L., Lee, K., Berelson, W., Kleypas, J., Fabry, V.J., Millero, F.J., 2004. Impact of anthropogenic $\mathrm{CO}_{2}$ on the $\mathrm{CaCO}_{3}$ system in the oceans. Science 305, 362-366. doi:10.1126/science.1097329

Feely, R.A., Sabine, C.L., Millero, F.J., Langdon, C., Dickson, A.G., Fine, R.A., Bullister, J.L., Hansell, D.A., Carlson, C.A., Sloyan, B.M., McNichol, A.P., Key, R.M., Byrne, R.H., Wanninkhof, R., 2009b. Carbon Dioxide, Hydrographic, and Chemical Data Obtained During the R/Vs Roger Revelle and Thomas Thompson Repeat Hydrography Cruises in the Pacific Ocean: CLIVAR CO2 Sections P16S_2005 (9 January-19 February, 2005) and P16N_2006 (13 February-30 March, 2006). ORNL/CDIAC-155, NDP-090. Kozyr, A. (Ed.). Carbon Dioxide Information Analysis Center, Oak Ridge National Laboratory, U.S. Department of Energy, Oak Ridge, Tennessee.

Friis, K., Kortzinger, A., Patsch, J., Wallace, D., 2005. On the temporal increase of anthropogenic $\mathrm{CO}_{2}$ in the subpolar North Atlantic. Deep-Sea Res. 52, 681-698. doi:10.1016/j.dsr.2004.11.017

GLOBALVIEW-CO2, 2013. Cooperative Global Atmospheric Data Integration Project. 2013, updated annually. Multi-laboratory compilation of synchronized and gapfilled atmospheric carbon dioxide records for the period 1979-2012 (obspack_co2_1_GLOBALVIEW-CO2_2013_v1.0.4_2013-12-23).

González-Dávila, M., Santana-Casiano, J.M., Rueda, M.J., Llinás, O., 2010. The water column distribution of carbonate system variables at the ESTOC site from 1995 to 2004. Biogeosciences 7, 3067-3081. doi:10.5194/bg-7-3067-2010

Goyet, C., Coatanoan, C., Eischeid, G., Amaoka, T., Okuda, K., Healy, R., Tsunogai, S., 1999. Spatial variation of total $\mathrm{CO}_{2}$ and total alkalinity in the northern Indian Ocean: A novel approach for the quantification of anthropogenic $\mathrm{CO}_{2}$ in seawater. J. Mar. Res. 57, 135-163. doi:10.1357/002224099765038599 
Gruber, N., 1998. Anthropogenic $\mathrm{CO}_{2}$ in the Atlantic Ocean. Global Biogeochem. Cycles. doi:10.1029/97GB03658

Gruber, N., Sarmiento, J.L., Stocker, T.F., 1996. An improved method for detecting anthropogenic $\mathrm{CO}_{2}$ in the oceans. Global Biogeochem. Cycles 10, 809-837. doi:10.1029/96GB01608

Hall, T.M., Haine, T.W.N., Waugh, D.W., 2002. Inferring the concentration of anthropogenic carbon in the ocean from tracers. Global Biogeochem. Cycles 16, 1131. doi:10.1029/2001GB001835

Hall, T.M., Waugh, D.W., Haine, T.W.N., Robbins, P.E., Khatiwala, S., 2004. Estimates of anthropogenic carbon in the Indian Ocean with allowance for mixing and timevarying air-sea $\mathrm{CO}_{2}$ disequilibrium. Global Biogeochem. Cycles 18, GB1031. doi:10.1029/2003GB002120

Hoppema, M., Roether, W., Bellerby, R.G.J., de Baar, H.J.W., 2001. Direct measurements reveal insignificant storage of anthropogenic $\mathrm{CO}_{2}$ in the Abyssal Weddell Sea. Geophys. Res. Lett. 28, 1747-1750. doi:10.1029/2000GL012443

Ishii, M., Kosugi, N., Sasano, D., Saito, S., Midorikawa, T., Inoue, H.Y., 2011. Ocean acidification off the south coast of Japan: A result from time series observations of $\mathrm{CO}_{2}$ parameters from 1994 to 2008. J. Geophys. Res. 116. doi:10.1029/2010JC006831

Ito, T., Woloszyn, M., Mazloff, M., 2010. Anthropogenic carbon dioxide transport in the Southern Ocean driven by Ekman flow. Nature 463, 80-3. doi:10.1038/nature08687

Jacobs, S.S., Amos, A.F., Bruchhausen, P.M., 1970. Ross Sea oceanography and Antarctic Bottom Water formation. Deep-Sea Res. 17, 935-962. doi:10.1016/00117471(70)90046-X

Johnson, K.M., King, A.E., Sieburth, J.M., 1985. Coulometric $\mathrm{TCO}_{2}$ analyses for marine studies; an introduction. Mar. Chem. doi:10.1016/0304-4203(85)90028-3

Johnson, K.M., Sieburth, J.M., Williams, P.J. leB, Brändström, L., 1987. Coulometric total carbon dioxide analysis for marine studies: Automation and calibration. Mar. Chem. doi:10.1016/0304-4203(87)90033-8

Johnson, K.M., Wills, K.D., Butler, D.B., Johnson, W.K., Wong, C.S., 1993. Coulometric total carbon dioxide analysis for marine studies: maximizing the performance of an automated gas extraction system and coulometric detector. Mar. Chem. doi:10.1016/0304-4203(93)90201-X

Keeling, R.F., Piper, S.C., Heimann, M., 1996. Global and hemispheric $\mathrm{CO}_{2}$ sinks deduced from changes in atmopheric $\mathrm{O}_{2}$ concentration. Nature 381, 218-221. 
Key, R.M., Kozyr, A., Sabine, C.L., Lee, K., Wanninkhof, R., Bullister, J.L., Feely, R.A., Millero, F.J., Mordy, C., Peng, T.-H., 2004. A global ocean carbon climatology:

Results from Global Data Analysis Project (GLODAP). Global Biogeochem. Cycles 18. doi:10.1029/2004GB002247

Key, R.M., Tanhua, T., Olsen, A., Hoppema, M., Jutterström, S., Schirnick, C., van Heuven, S., Kozyr, A., Lin, X., Velo, A., Wallace, D.W.R., Mintrop, L., 2010. The CARINA data synthesis project: introduction and overview. Earth Syst. Sci. Data 2, 105-121. doi:10.5194/essd-2-105-2010

Khatiwala, S., Primeau, F., Hall, T., 2009. Reconstruction of the history of anthropogenic $\mathrm{CO}_{2}$ concentrations in the ocean. Nature 462, 346-9. doi:10.1038/nature08526

Khatiwala, S., Tanhua, T., Mikaloff Fletcher, S., Gerber, M., Doney, S.C., Graven, H.D., Gruber, N., McKinley, G.A., Murata, A., Ríos, A.F., Sabine, C.L., 2013. Global ocean storage of anthropogenic carbon. Biogeosciences 10, 2169-2191. doi:10.5194/bg-10-2169-2013

Le Quéré, C., Moriarty, R., Andrew, R.M., Peters, G.P., Ciais, P., Friedlingstein, P., Jones, S.D., Sitch, S., Tans, P., Arneth, A., Boden, T.A., Bopp, L., Bozec, Y., Canadell, J.G., Chevallier, F., Cosca, C.E., Harris, I., Hoppema, M., Houghton, R.A., House, J.I., Jain, A., Johannessen, T., Kato, E., Keeling, R.F., Kitidis, V., Klein Goldewijk, K., Koven, C., Landa, C.S., Landschützer, P., Lenton, A., Lima, I.D., Marland, G., Mathis, J.T., Metzl, N., Nojiri, Y., Olsen, A., Ono, T., Peters, W., Pfeil, B., Poulter, B., Raupach, M.R., Regnier, P., Rödenbeck, C., Saito, S., Salisbury, J.E., Schuster, U., Schwinger, J., Séférian, R., Segschneider, J., Steinhoff, T., Stocker, B.D., Sutton, A.J., Takahashi, T., Tilbrook, B., van der Werf, G.R., Viovy, N., Wang, Y.-P., Wanninkhof, R., Wiltshire, A., Zeng, N., 2014. Global carbon budget 2014. Earth Syst. Sci. Data Discuss. 7, 521-610. doi:10.5194/essdd7-521-2014

Lee, K., Choi, S.-D., Park, G.-H., Wanninkhof, R., Peng, T.-H., Key, R.M., Sabine, C.L., Feely, R.A., Bullister, J.L., Millero, F.J., Kozyr, A., 2003. An updated anthropogenic $\mathrm{CO}_{2}$ inventory in the Atlantic Ocean. Global Biogeochem. Cycles 17. doi:10.1029/2003GB002067

Lewis, E., Wallace, D.W.R., 1998. Program Developed for $\mathrm{CO}_{2}$ System Calculations. ORNL/CDIAC-105.

Lo Monaco, C., 2005. Anthropogenic $\mathrm{CO}_{2}$ in the Southern Ocean: Distribution and inventory at the Indian-Atlantic boundary (World Ocean Circulation Experiment line I6). J. Geophys. Res. 110, C06010. doi:10.1029/2004JC002643

Lueker, T.J., Dickson, A.G., Keeling, C.D., 2000. Ocean $\mathrm{pCO}_{2}$ calculated from dissolved inorganic carbon, alkalinity, and equations for $\mathrm{K}_{1}$ and $\mathrm{K}_{2}$ : validation based on 
laboratory measurements of $\mathrm{CO}_{2}$ in gas and seawater at equilibrium. Mar. Chem. 70, 105-119. doi:10.1016/S0304-4203(00)00022-0

Matear, R.J., Hirst, A.C., McNeil, B.I., 2000. Changes in dissolved oxygen in the Southern Ocean with climate change. Geochem. Geophys. Geosyst. 1. doi:10.1029/2000GC000086

Matear, R.J., McNeil, B.I., 2003. Decadal accumulation of anthropogenic $\mathrm{CO}_{2}$ in the Southern Ocean: A comparison of CFC-age derived estimates to multiple-linear regression estimates. Global Biogeochem. Cycles 17. doi:10.1029/2003GB002089

McNeil, B.I., Matear, R.J., Key, R.M., Bullister, J.L., Sarmiento, J.L., 2003. Anthropogenic $\mathrm{CO}_{2}$ uptake by the ocean based on the global chlorofluorocarbon data set. Science 299, 235-239. doi:10.1126/science.1077429

Midorikawa, T., Inoue, H.Y., Ishii, M., Sasano, D., Kosugi, N., Hashida, G., Nakaoka, S., Suzuki, T., 2012. Decreasing pH trend estimated from 35-year time series of carbonate parameters in the Pacific sector of the Southern Ocean in summer. DeepSea Res. 61, 131-139. doi:10.1016/j.dsr.2011.12.003

Midorikawa, T., Ishii, M., Saito, S., Sasano, D., Kosugi, N., Motoi, T., Kamiya, H., Nakadate, A., Nemoto, K., Inoue, H.Y., 2010. Decreasing pH trend estimated from 25-yr time series of carbonate parameters in the western North Pacific. Tellus B 62B, 649-659. doi:10.1111/j.1600-0889.2010.00474.x

Murata, A., Kumamoto, Y., Sasaki, K., Watanabe, S., Fukasawa, M., 2008. Decadal increases of anthropogenic $\mathrm{CO}_{2}$ in the subtropical South Atlantic Ocean along $30^{\circ} \mathrm{S}$. J. Geophys. Res. 113, C06007. doi:10.1029/2007JC004424

Murata, A., Kumamoto, Y., Sasaki, K., Watanabe, S., Fukasawa, M., 2009. Decadal increases of anthropogenic $\mathrm{CO}_{2}$ along $149^{\circ} \mathrm{E}$ in the western North Pacific. J. Geophys. Res. 114, C04018. doi:10.1029/2008JC004920

Murata, A., Kumamoto, Y., Sasaki, K., Watanabe, S., Fukasawa, M., 2010. Decadal increases in anthropogenic $\mathrm{CO}_{2}$ along $20^{\circ} \mathrm{S}$ in the South Indian Ocean. J. Geophys. Res. 115, C12055. doi:10.1029/2010JC006250

Murata, A., Kumamoto, Y., Watanabe, S., Fukasawa, M., 2007. Decadal increases of anthropogenic $\mathrm{CO}_{2}$ in the South Pacific subtropical ocean along $32^{\circ} \mathrm{S}$. J. Geophys. Res. 112, C05033. doi:10.1029/2005JC003405

National Research Council, 2011. Future Science Opportunities in Antarctica and the Southern Ocean. The National Academies Press, Washington, D.C.

Naveira Garabato, A.C., Jullion, L., Stevens, D.P., Heywood, K.J., King, B.A., 2009. Variability of Subantarctic Mode Water and Antarctic Intermediate Water in the 
Drake Passage during the Late-Twentieth and Early-Twenty-First Centuries. J. Clim. 22, 3661-3688. doi:10.1175/2009JCLI2621.1

Olafsson, J., Olafsdottir, S.R., Benoit-Cattin, A., Danielsen, M., Arnarson, T.S., Takahashi, T., 2009. Rate of Iceland Sea acidification from time series measurements. Biogeosciences 6, 2661-2668. doi:10.5194/bg-6-2661-2009

Olsen, A., Omar, A.M., Bellerby, R.G.J., Johannessen, T., Ninnemann, U., Brown, K.R., Olsson, K.A., Olafsson, J., Nondal, G., Kivimäe, C., Kringstad, S., Neill, C., Olafsdottir, S., 2006. Magnitude and origin of the anthropogenic $\mathrm{CO}_{2}$ increase and ${ }^{13} \mathrm{C}$ Suess effect in the Nordic seas since 1981. Global Biogeochem. Cycles 20. doi:10.1029/2005GB002669

Orr, J.C., 2004. Modelling of Ocean Storage of CO2-The GOSAC Study. Cheltenham, U.K.

Orr, J.C., 2011. Recent and future changes in ocean carbonate chemistry, in: Ocean Acidification. Oxford University Press, New York, pp. 41-66.

Orr, J.C., Fabry, V.J., Aumont, O., Bopp, L., Doney, S.C., Feely, R. a, Gnanadesikan, A., Gruber, N., Ishida, A., Joos, F., Key, R.M., Lindsay, K., Maier-Reimer, E., Matear, R., Monfray, P., Mouchet, A., Najjar, R.G., Plattner, G.-K., Rodgers, K.B., Sabine, C.L., Sarmiento, J.L., Schlitzer, R., Slater, R.D., Totterdell, I.J., Weirig, M.-F., Yamanaka, Y., Yool, A., 2005. Anthropogenic ocean acidification over the twentyfirst century and its impact on calcifying organisms. Nature 437, 681-686. doi:10.1038/nature04095

Orsi, A.H., Johnson, G.C., Bullister, J.L., 1999. Circulation, mixing, and production of Antarctic Bottom Water. Prog. Oceanogr. 43, 55-109. doi:10.1016/S00796611(99)00004-X

Orsi, A.H., Whitworth, T.I., 2005. Hydrographic Atlas of the World Ocean Circulation Experiment (WOCE). Volume 1: Southern Ocean. International WOCE Project Office, Southampton, U.K.

Orsi, A.H., Whitworth, T.I., Nowlin, W.D.J., 1995. On the meridional extent and fronts of the Antarctic Circumpolar Current. Deep-Sea Res. I. doi:10.1016/09670637(95)00021-W

Pardo, P.C., Pérez, F.F., Khatiwala, S., Ríos, A.F., 2014. Anthropogenic $\mathrm{CO}_{2}$ estimates in the Southern Ocean: Storage partitioning in the different water masses. Prog. Oceanogr. 120, 230-242. doi:10.1016/j.pocean.2013.09.005

Peng, T.-H., Wanninkhof, R., 2010. Increase in anthropogenic $\mathrm{CO}_{2}$ in the Atlantic Ocean in the last two decades. Deep-Sea Res. I 57, 755-770. doi:10.1016/j.dsr.2010.03.008 
Peng, T.-H., Wanninkhof, R., Bullister, J.L., Feely, R.A., Takahashi, T., 1998.

Quantification of decadal anthropogenic $\mathrm{CO}_{2}$ uptake in the ocean based on dissolved inorganic carbon measurements. Nature 396, 560-563. doi:10.1038/25103

Peng, T.-H., Wanninkhof, R., Feely, R.A., 2003. Increase of anthropogenic $\mathrm{CO}_{2}$ in the Pacific Ocean over the last two decades. Deep-Sea Res. II 50, 3065-3082. doi:10.1016/j.dsr2.2003.09.001

Pérez, F.F., Álvarez, M., Ríos, A.F., 2002. Improvements on the back-calculation technique for estimating anthropogenic $\mathrm{CO}_{2}$. Deep Sea Res. 49, 859-875. doi:10.1016/S0967-0637(02)00002-X

Poisson, A., Chen, C.-T.A., 1987. Why is there little anthropogenic $\mathrm{CO}_{2}$ in the Antarctic Bottom Water? Deep-Sea Res. 34, 1255-1275. doi:10.1016/0198-0149(87)90075-6

Popp, B.N., Trull, T., Kenig, F., Wakeham, S.G., Rust, T.M., Tilbrook, B., Griffiths, F.B., Wright, S.W., Marchant, H.J., Bidigare, R.R., Laws, E.A., 1999. Controls on the carbon isotopic composition of Southern Ocean phytoplankton. Global Biogeochem. Cycles 13, 827-843. doi:10.1029/1999GB900041

Quay, P., Sonnerup, R., Stutsman, J., Maurer, J., Körtzinger, A., Padin, X.A., Robinson, C., 2007. Anthropogenic $\mathrm{CO}_{2}$ accumulation rates in the North Atlantic Ocean from changes in the ${ }^{13} \mathrm{C} /{ }^{12} \mathrm{C}$ of dissolved inorganic carbon. Global Biogeochem. Cycles 21. doi:10.1029/2006GB002761

Quay, P., Sonnerup, R., Westby, T., Stutsman, J., McNichol, A., 2003. Changes in the ${ }^{13} \mathrm{C} /{ }^{12} \mathrm{C}$ of dissolved inorganic carbon in the ocean as a tracer of anthropogenic $\mathrm{CO}_{2}$ uptake. Global Biogeochem. Cycles 17. doi:10.1029/2001GB001817

Quay, P., Tilbrook, B., Wong, C., 1992. Oceanic Uptake of Fossil fFuel CO 2 : Carbon-13 Evidence. Science 256, 74-79. doi:10.1126/science.256.5053.74

Rhein, M., Rintoul, S.R., Aoki, S., Campos, E., Chambers, D., Feely, R.A., Gulev, S., Johnson, G.C., Josey, S.A., Kostianoy, A., Mauritzen, C., Roemmich, D., Talley, L.D., Wang, F., 2013. Observations: Ocean, in: Stocker, T.F., Qin, D., Plattner, G.K., Tignor, M., Allen, S.K., Boschung, J., Nauels, A., Xia, Y., Bex, V., Midgley, P.M. (Eds.), Climate Change 2013: The Physical Science Basis. Contribution of Working Group I to the Fifth Assessment Report of the Intergovernmental Panel on Climate Change. Cambridge University Press, Cambridge, United Kingdom and New York, NY, USA, pp. 255-315.

Rusell, J.L., Stouffer, R.J., Dixon, K.W., 2006. Intercomparison of the Southern Ocean circulations in IPCC coupled model control simulations. J. Clim. 19, 4560-4575. doi:10.1175/JCLI3869.1 
Russell, J.L., Dickson, A.G., 2003. Variability in oxygen and nutrients in South Pacific Antarctic Intermediate Water. Global Biogeochem. Cycles 17, 1033.

doi:10.1029/2000GB001317

Sabine, C.L., Feely, R.A., 2007. The oceanic sink for carbon dioxide, in: Reay, D., Hewitt, N., Grace, J., Smith, K. (Eds.), Greenhouse Gas Sinks. CABI Publishing, Oxfordshire, U.K., pp. 31-49.

Sabine, C.L., Feely, R.A., Gruber, N., Key, R.M., Lee, K., Bullister, J.L., Wanninkhof, R., Wong, C.S., Wallace, D.W.R., Tilbrook, B., Millero, F.J., Peng, T.-H., Kozyr, A., Ono, T., Rios, A.F., 2004a. The oceanic sink for anthropogenic $\mathrm{CO}_{2}$. Science 305, 367-371. doi:10.1126/science.1097403

Sabine, C.L., Feely, R.A., Gruber, N., Key, R.M., Lee, K., Bullister, J.L., Wanninkhof, R., Wong, C.S., Wallace, D.W.R., Tilbrook, B., Millero, F.J., Peng, T.-H., Kozyr, A., Ono, T., Rios, A.F., 2004b. The oceanic sink for anthropogenic $\mathrm{CO}_{2}$ :

Supplemental Information. Science 305, 367-371. doi:10.1126/science.1097403

Sabine, C.L., Feely, R.A., Key, R.M., Bullister, J.L., Millero, F.J., Lee, K., Peng, T.-H., Tilbrook, B., Ono, T., Wong, C.S., 2002. Distribution of anthropogenic $\mathrm{CO}_{2}$ in the Pacific Ocean. Global Biogeochem. Cycles 16, 30-1-30-17.

doi:10.1029/2001GB001639

Sabine, C.L., Feely, R.A., Key, R.M., Wanninkhof, R., Millero, F.J., Peng, T.-H., Bullister, J.L., Kozyr, A., 2004c. Global Ocean Data Analysis Project (GLODAP): Results and Data, Global Biogeochemical Cycles. Oak Ridge, Tennessee.

Sabine, C.L., Feely, R.A., Millero, F.J., Dickson, A.G., Langdon, C., Mecking, S., Greeley, D., 2008. Decadal changes in Pacific carbon. J. Geophys. Res. 113, 96 pp. doi:10.1029/2007JC004577

Sabine, C.L., Feely, R.A., Wanninkhof, R., Dickson, A.G., Millero, F.J., Hansell, D.A., Swift, J.H., 2012. Carbon Dioxide, Hydrographic, and Chemical Data Obtained During the R/V Nathaniel B. Palmer Cruise in the Southern Ocean on CLIVAR Repeat Hydrography Section S04P (Feb. 19 - Apr. 23, 2011). Oak Ridge, Tennessee. doi:10.3334/CDIAC/OTG.CLIVAR_S04P_2011

Sabine, C.L., Heimann, M., Artaxo, P., Bakker, D.C.E., Chen, C.-T.A., Field, C.B., Gruber, N., Le Quéré, C., Prinn, R.G., Richey, J.E., Lankao, P.R., Sathaye, J.A., Valentini, R., 2004d. The Global Carbon Cycle: Integrating Humans, Climate, and the Natural World, in: Field, C.B., Raupach, M.R. (Eds.), The Global Carbon Cycle: Integrating Humans, Climate, and the Natural World. Island Press, Washington, D.C., pp. 17-44. 
Sabine, C.L., Key, R.M., Johnson, K.M., Millero, F.J., Poisson, A., Sarmiento, J.L., Wallace, D.W.R., Winn, C.D., 1999. Anthropogenic $\mathrm{CO}_{2}$ inventory of the Indian Ocean. Global Biogeochem. Cycles 13, 179-198.

Sabine, C.L., Tanhua, T., 2010. Estimation of Anthropogenic $\mathrm{CO}_{2}$ Inventories in the Ocean. Ann. Rev. Mar. Sci. 2, 175-198. doi:10.1146/annurev-marine-120308080947

Sallée, J.-B., Matear, R.J., Rintoul, S.R., Lenton, A., 2012. Localized subduction of anthropogenic carbon dioxide in the Southern Hemisphere oceans. Nat. Geosci. 5, 579-584. doi:10.1038/ngeo1523

Sarmiento, J., 1992. A Perturbation Simulation of $\mathrm{CO}_{2}$ Uptake in an Ocean General Circulation Model. J. Geophys. Res. 97, 3621-3645.

Sarmiento, J.L., Gruber, N., 2002. Sinks for anthropogenic carbon. Phys. Today 55(8), 30-36. doi:10.1063/1.1510279

Siegenthaler, U., Sarmiento, J., 1993. Atmospheric carbon dioxide and the ocean. Nature $365,119-125$.

Sloyan, B.M., Swift, J.H., 2009. Preliminary Cruise Report: P16S_2005A [WWW Document]. URL http://cchdo.ucsd.edu/data/b/c28631/p16s_2005ado.pdf

Speer, K., Rintoul, S.R., Sloyan, B., 2000. The Diabatic Deacon Cell. J. Phys. Oceanogr. doi:10.1175/1520-0485(2000)030<3212:TDDC>2.0.CO;2

Swift, J., Orsi, A., 2012. Sixty-Four Days of Hydrography and Storms: RVIB Nathaniel B. Palmer's 2011 S04P Cruise. Oceanography 25, 54-55. doi:10.5670/oceanog.2012.74

Swift, J.H., Orsi, A.H., 2011. Cruise Report: S04P [WWW Document]. URL http://cchdo.ucsd.edu/data/b/c35209/s04p_320620110219do.pdf

Takahashi, T., Sutherland, S.C., Chipman, D.W., Goddard, J.G., Ho, C., 2014. Climatological distributions of $\mathrm{pH}, \mathrm{pCO}_{2}$, total $\mathrm{CO}_{2}$, alkalinity, and $\mathrm{CaCO}_{3}$ saturation in the global surface ocean, and temporal changes at selected locations. Mar. Chem. 164, 95-125. doi:10.1016/j.marchem.2014.06.004

Takahashi, T., Sutherland, S.C., Wanninkhof, R., Sweeney, C., Feely, R.A., Chipman, D.W., Hales, B., Friederich, G., Chavez, F., Sabine, C., Watson, A., Bakker, D.C.E., Schuster, U., Metzl, N., Yoshikawa-Inoue, H., Ishii, M., Midorikawa, T., Nojiri, Y., Körtzinger, A., Steinhoff, T., Hoppema, M., Olafsson, J., Arnarson, T.S., Tilbrook, B., Johannessen, T., Olsen, A., Bellerby, R., Wong, C.S., Delille, B., Bates, N.R., de Baar, H.J.W., 2009. Climatological mean and decadal change in surface ocean 
$\mathrm{pCO}_{2}$, and net sea-air $\mathrm{CO}_{2}$ flux over the global oceans. Deep-Sea Res. II 56, 554577. doi:10.1016/j.dsr2.2008.12.009

Takahashi, T., Sweeney, C., Hales, B., Chipman, D.W., Newberger, T., Goddard, J.G., Iannuzzi, R.A., Sutherland, S.C., 2012. The Changing Carbon Cycle in the Southern Ocean. Oceanography. doi:10.5670/oceanog.2012.71

Talley, L.D., 2007. Hydrographic Atlas of the World Ocean Circulation Experiment (WOCE). Volume 2: Pacific Ocean. International WOCE Project Office, Southampton, U.K.

Talley, L.D., Pickard, G.L., Emery, W.J., Swift, J.H., 2011. Descriptive Physical Oceanography: An Introduction, 6th ed. Elsevier Ltd., London.

Tanhua, T., 2010. Matlab Toolbox to Perform Secondary Quality Control ( $2^{\text {nd }}$ QC) on Hydrographic Data. Carbon Dioxide Information Analysis Center, Oak Ridge National Laboratory, U.S. Department of Energy, Oak Ridge, Tennessee. doi:10.3334/CDIAC/otg.CDIAC

Tanhua, T., Heuven, S. Van, Key, R.M., Velo, A., Olsen, A., Schirnick, C., 2010. Quality control procedures and methods of the CARINA database. Earth Syst. 35-49. doi:10.3334/CDIAC/otg.CARINA.SO.V1.0

Tanhua, T., Körtzinger, A., Friis, K., Waugh, D.W., Wallace, D.W.R., 2007. An estimate of anthropogenic $\mathrm{CO}_{2}$ inventory from decadal changes in oceanic carbon content. Proc. Natl. Acad. Sci. U. S. A. 104, 3037-3042. doi:10.1073/pnas.0606574104

Tans, P., 2009. An Accounting of the Observed Increase in Oceanic and Atmospheric CO2 and the Outlook for the Future. Oceanography. doi:10.5670/oceanog.2009.94

Touratier, F., Azouzi, L., Goyet, C., 2007. CFC-11, $\Delta 14 \mathrm{C}$ and $3 \mathrm{H}$ tracers as a means to assess anthropogenic $\mathrm{CO} 2$ concentrations in the ocean. Tellus 59B, 318-325. doi:10.1111/j.1600-0889.2006.00247.x

Van Heuven, S., Pierrot, D., Rae, J.W.B., Lewis, E., Wallace, D.W.R., 2011. MATLAB Program Developed for $\mathrm{CO}_{2}$ System Calculations. ORNL/CDIAC-105b. Carbon Dioxide Information Analysis Center, Oak Ridge National Laboratory, U.S. Department of Energy, Oak Ridge, Tennessee. doi:10.3334/CDIAC/otg.CO2SYS_MATLAB_v1.1

Wakita, M., Watanabe, S., Murata, A., Tsurushima, N., Honda, M., 2010. Decadal change of dissolved inorganic carbon in the subarctic western North Pacific Ocean. Tellus B 62, 608-620. doi:10.1111/j.1600-0889.2010.00476.x

Wallace, D., 1995. Monitoring Global Ocean Carbon Inventories. College Station, TX. 
Wanninkhof, R., Doney, S.C., Bullister, J.L., Levine, N.M., Warner, M., Gruber, N., 2010. Detecting anthropogenic $\mathrm{CO}_{2}$ changes in the interior Atlantic Ocean between 1989 and 2005. J. Geophys. Res. 115, C11028. doi:10.1029/2010JC006251

Waters, J.F., Millero, F.J., Sabine, C.L., 2011. Changes in South Pacific anthropogenic carbon. Global Biogeochem. Cycles 25, GB4011. doi:10.1029/2010GB003988

Waugh, D.W., Haine, T.W.N., Hall, T.M., 2004. Transport times and anthropogenic carbon in the subpolar North Atlantic Ocean. Deep-Sea Res. 51, 1475-1491. doi:10.1016/j.dsr.2004.06.011

Waugh, D.W., Primeau, F., Devries, T., Holzer, M., 2013. Recent changes in the ventilation of the southern oceans. Science 339, 568-70. doi:10.1126/science.1225411

Xue, L., Yu, W., Wang, H., Jiang, L.-Q., Feng, L., Gao, L., Li, K., Li, Z., Wei, Q., Ning, C., 2014. Temporal changes in surface partial pressure of carbon dioxide and carbonate saturation state in the eastern equatorial Indian Ocean during the 19622012 period. Biogeosciences 11, 6293-6305. doi:10.5194/bg-11-6293-2014

Yoshikawa-Inoue, H., Ishii, M., 2005. Variations and trends of $\mathrm{CO}_{2}$ in the surface seawater in the Southern Ocean south of Australia between 1969 and 2002. Tellus B 57B, 58-69. doi:10.1111/j.1600-0889.2005.00130.x 


\section{Figure Captions}

Figure 1. Map of S04P and P16S stations occupied from westernmost to easternmost during February-April 2011.

Figure 2. A depiction of the large-scale Southern Ocean circulation processes occurring in the study region. Thick red arrows indicate the mean flow of the Antarctic Slope Current and the Antarctic Circumpolar Current (ACC), orange arrows indicate water mass circulation, yellow arrows indicate the direction of the prevailing winds, and transparent red lines indicate the locations of the S04P and P16S hydrographic lines relative to these features. (Adapted from National Research Council 2011)

Figure 3. (a) Potential temperature $(\Theta)$, (b) Salinity, and (c) DIC (Dissolved Inorganic Carbon) measured in 2011 along the S04P (left) and P16S (right) transects. Thick black contours correspond to constant neutral density and the thick black vertical line denotes the crossover point between S04P and P16S.

Figure 4. (a) Measured DIC change along the S04P (left) and P16S (right) transects highlighting seasonal and interannual variability in surface waters and movement of water masses, (b) Apparent Oxygen Utilization (AOU) change measured along S04P (left) and P16S (right). Thick black contours correspond to constant neutral density and the thick vertical black line denotes the crossover point between S04P and P16S.

Figure 5. (a) $\Delta \mathrm{C}_{\text {Total, }}$ total carbon change calculated from eMLR using Eqs. (3)-(5), (b) $\triangle \mathrm{C}_{\mathrm{AOU}}$, carbon change due to AOU changes calculated from eMLR using Eq. (6), (c) $\Delta \mathrm{C}_{\text {Anth, }}$ anthropogenic carbon change calculated from the difference between (a) and (b) using Eq. (7) along S04P (2011-1992) (left) and P16S (2011-2005) (right). Thick black contours correspond to neutral density layers used for the MLR fits and the thick black vertical line denotes the crossover point between S04P and P16S.

Figure 6. S04P (left) and P16S (right) annual column inventory changes of $\Delta \mathrm{C}_{\text {Total }}$ (blue line), $\Delta \mathrm{C}_{\mathrm{AOU}}$ (green line), and $\Delta \mathrm{C}_{\text {Anth }}$ (red line).

Figure 7. (a) Anthropogenic $\mathrm{pH}$ change and (b) anthropogenic aragonite saturation state ( $\left.\Omega_{\text {Aragonite }}\right)$ change along S04P (2011-1992, 19 years) and P16S (2011-2005, 6 years). A neutral density contour $\left(27.75 \mathrm{~kg} \mathrm{~m}^{-3}\right)$ is overlaid in thick black contours and the crossover point between S04P and P16S is shown with a vertical black line. 


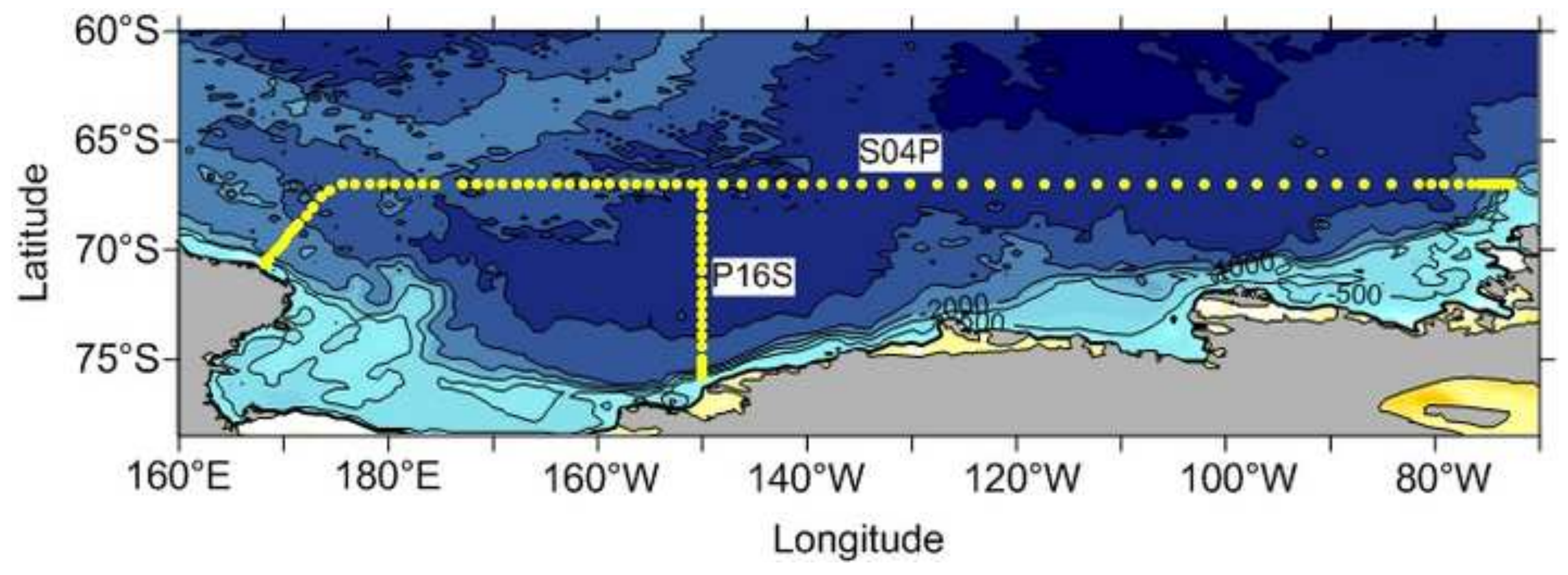




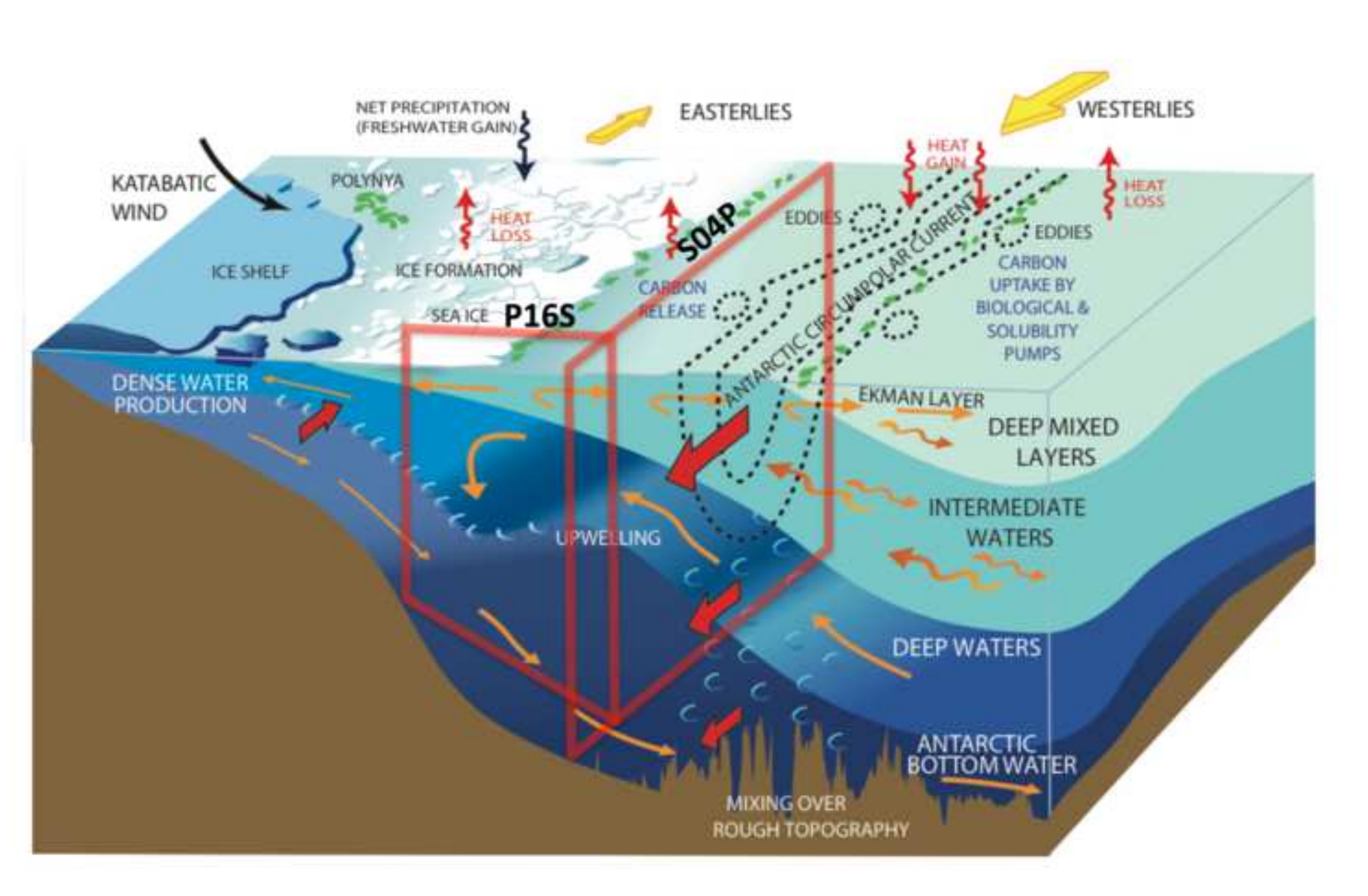

DENSE WATER N

NET PRECIPITA IION

.
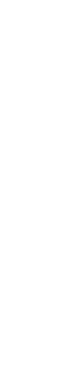
Potential Temperature $(\theta)$

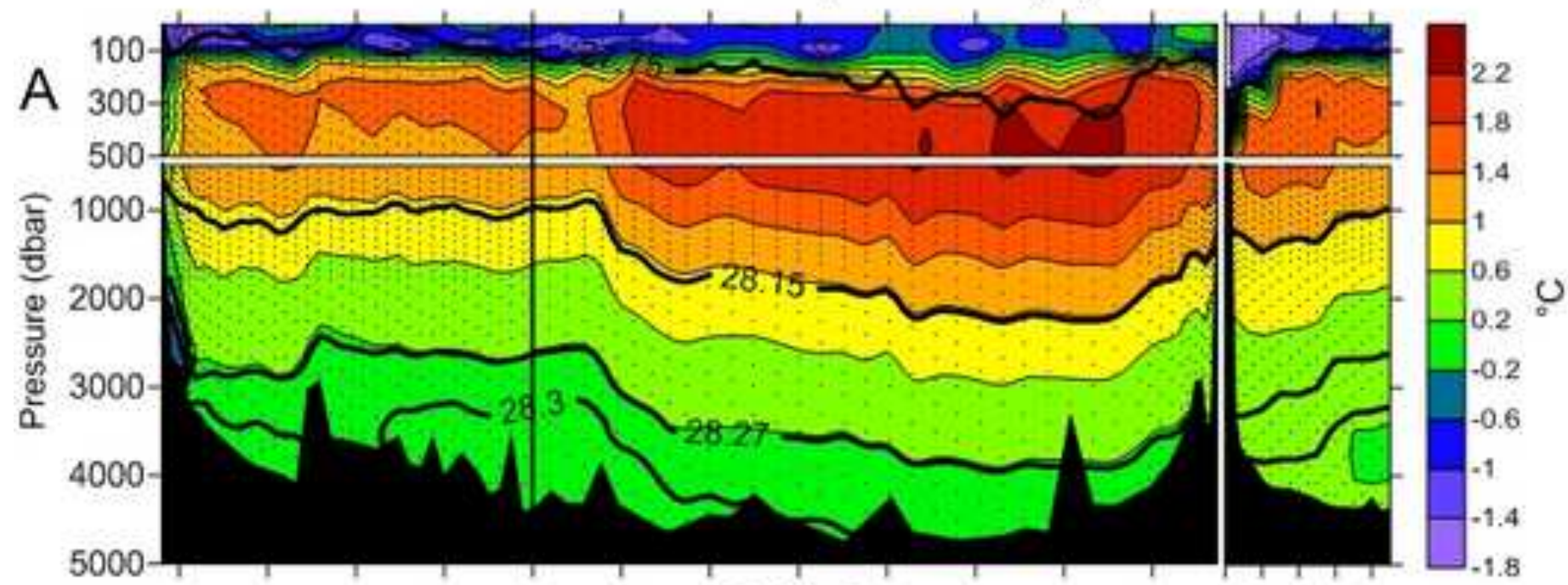

Salinity

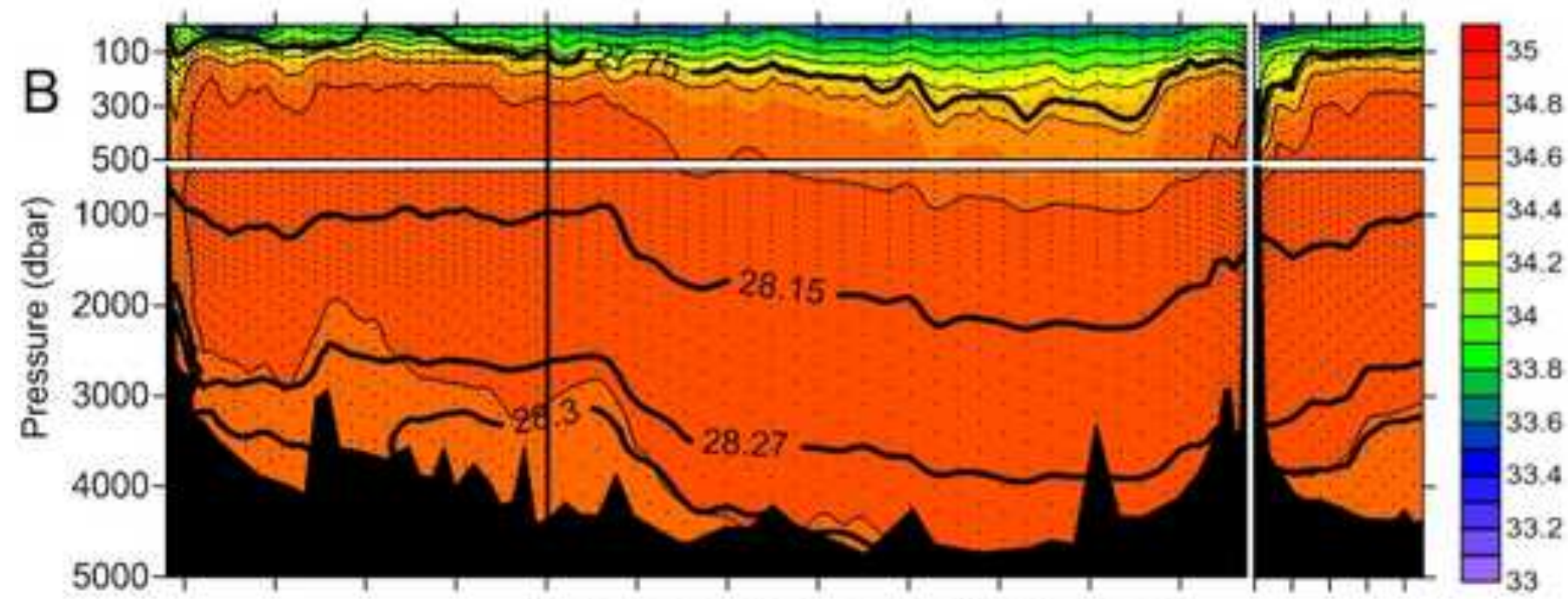

\section{Dissolved Inorganic Carbon}

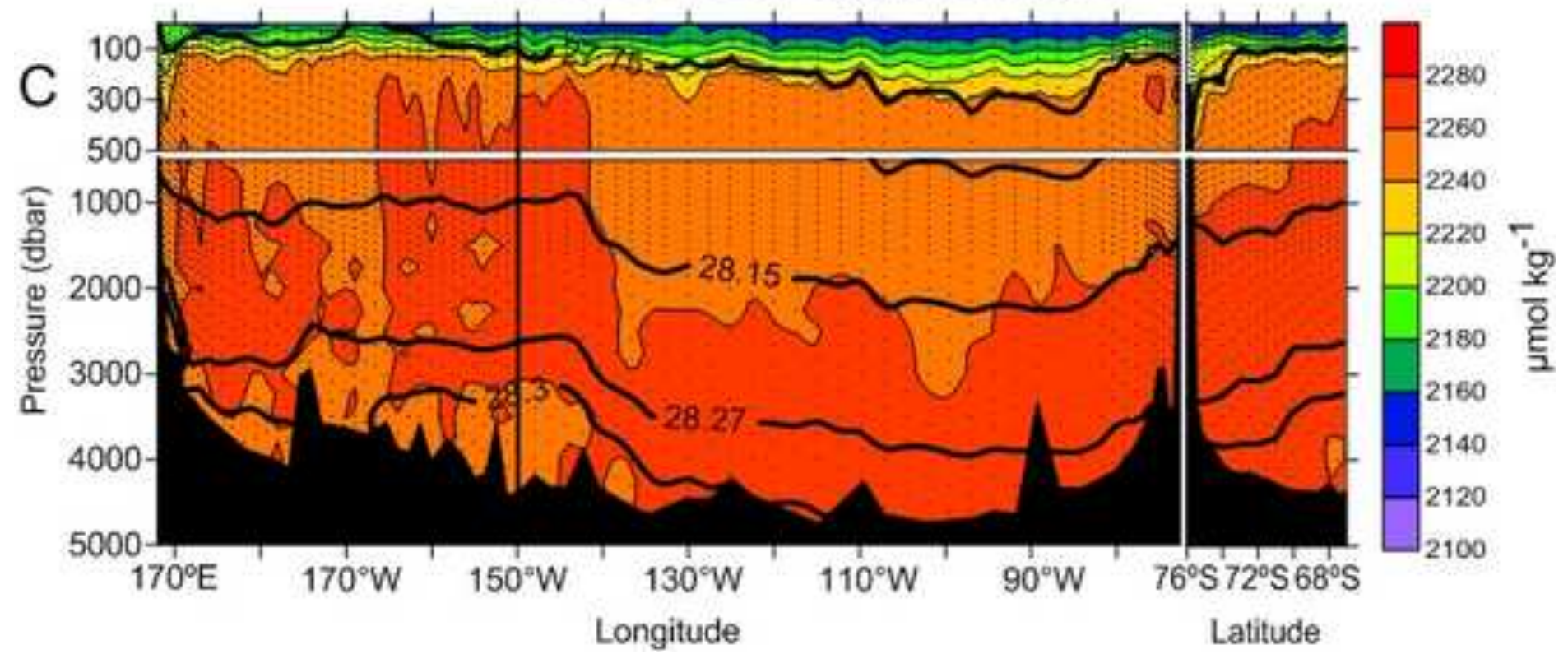


Dissolved Inorganic Carbon Change
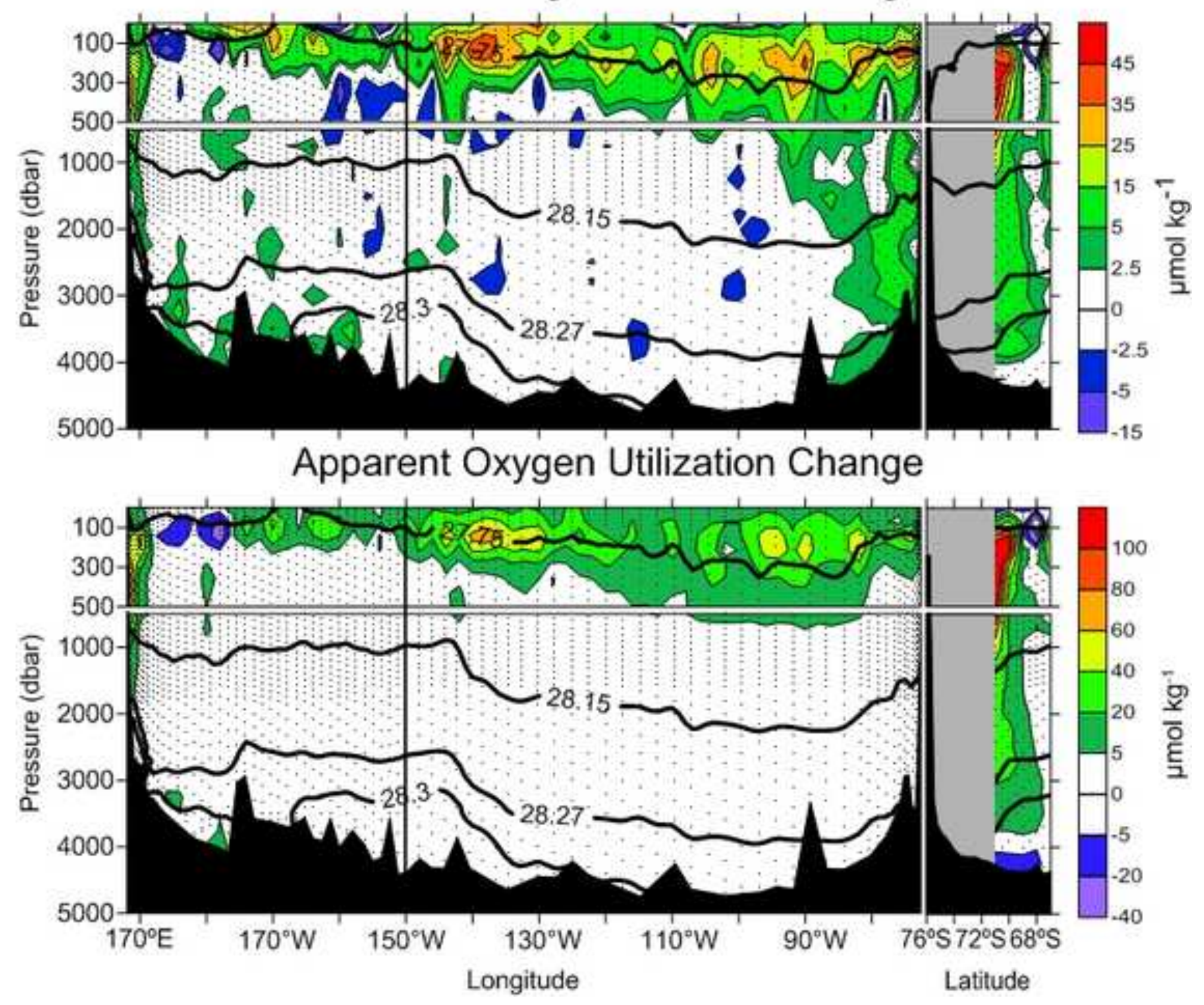


\section{$\Delta \mathrm{C}_{\text {Total }}$ from eMLR}
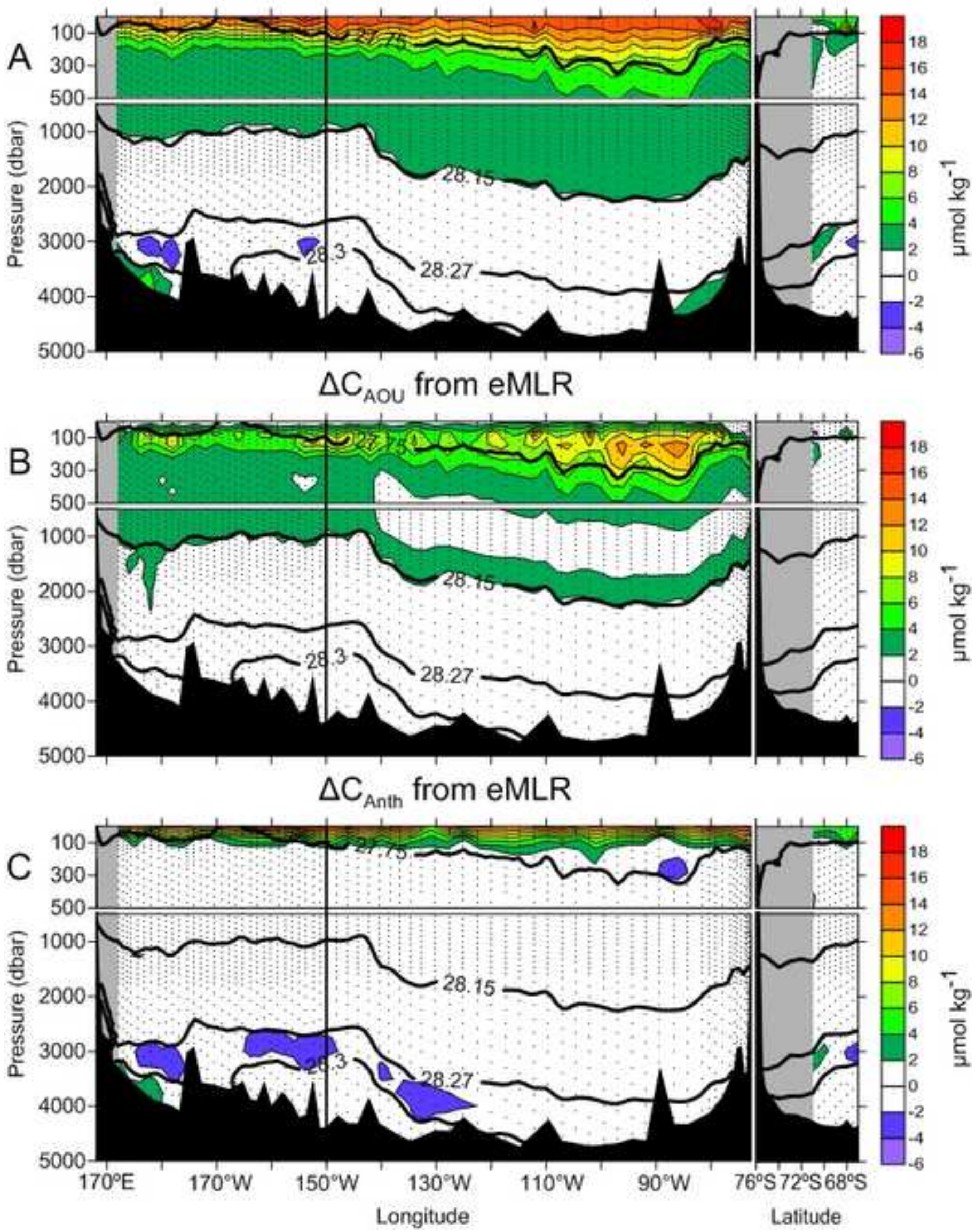


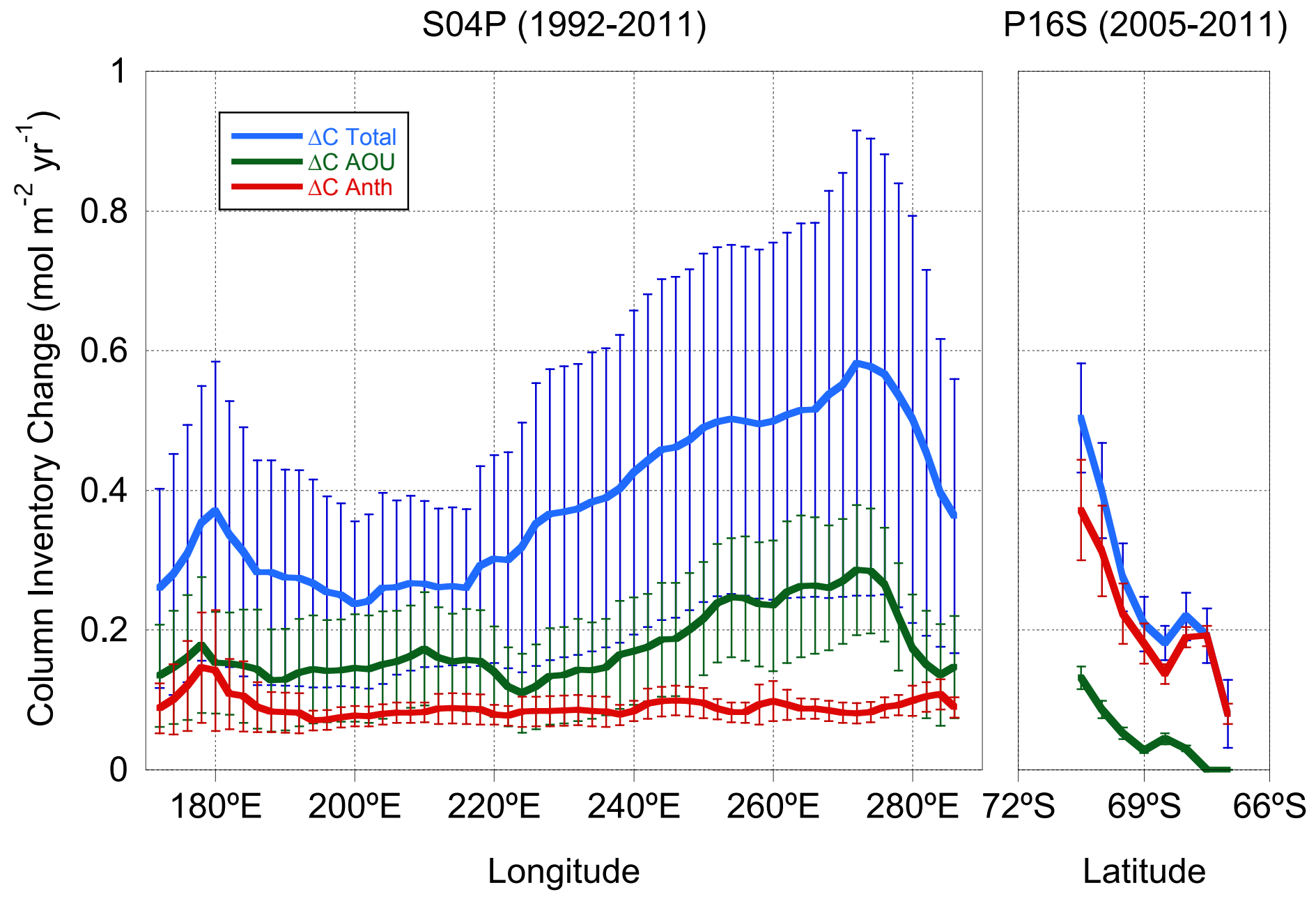



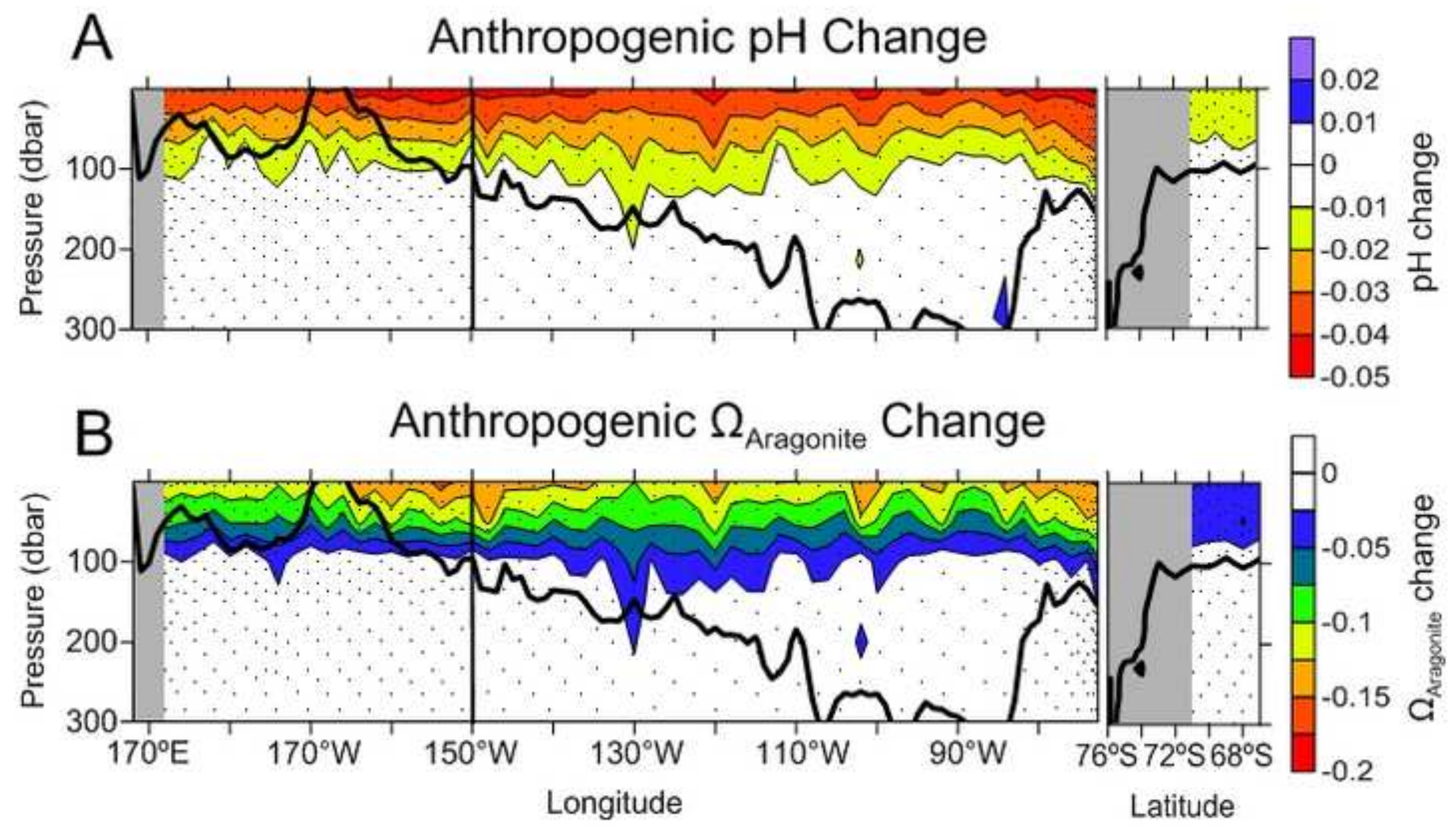
Table 1. A summary of carbon and oxygen measurements used in this study

\begin{tabular}{ccccc}
\hline Year & Parameter & Number & Uncertainty & Method \\
\hline 1992 & DIC & 1119 & $\pm 1.8 \mu \mathrm{mol} \mathrm{kg}$ & Coulometric titration \\
1992 & pCO $_{2}$ & 1112 & $\pm 0.12 \%(\mathrm{ppm})$ & Equilibrator-infrared gas analyzer \\
1992 & Oxygen & 2329 & $\pm 0.5 \mu \mathrm{mol} \mathrm{kg}$ & Automated titration \\
2005 & DIC & 257 & $\pm 2.0 \mu \mathrm{mol} \mathrm{kg}$ & Coulometric titration \\
2005 & TA & 257 & $\pm 1.1 \mu \mathrm{mol} \mathrm{kg}$ & HCl titration \\
2005 & Oxygen & 309 & $\pm 0.5 \mu \mathrm{mol} \mathrm{kg}$ & Automated titration \\
2011 & DIC & 2439 & $\pm 1.9 \mu \mathrm{mol} \mathrm{kg}$ & Coulometric titration \\
2011 & TA & 2420 & $\pm 1.0 \mu \mathrm{mol} \mathrm{kg}$ & HCl titration \\
2011 & Oxygen & 3762 & $\pm 0.5 \mu \mathrm{mol} \mathrm{kg}$ & Automated titration \\
\hline
\end{tabular}


Table 2. Neutral density $\left(\gamma^{\mathrm{n}}\right)$ surfaces

\begin{tabular}{cc}
\hline Water Mass & $\gamma^{\mathrm{n}}\left(\mathrm{kg} \mathrm{m}^{-3}\right)$ \\
\hline AASW & $<27.75$ \\
UCDW & $27.75-28.15$ \\
LCDW & $28.15-28.27$ \\
AABW & $28.27-28.3$ \\
'New' AABW & $>28.3$ \\
\hline
\end{tabular}


Table 3. DIC MLR fit coefficients

\begin{tabular}{|c|c|c|c|c|c|c|c|c|}
\hline \multicolumn{8}{|l|}{ Cruise } & \multirow{2}{*}{$\begin{array}{l}\text { std. error } \\
\mu \mathrm{mol} \mathrm{kg}\end{array}$} \\
\hline$\gamma^{\mathrm{n}}$ layer & $a$ & $b$ & $c$ & $d$ & $e$ & $f$ & $n^{a}$ & \\
\hline \multicolumn{9}{|c|}{$\overline{\text { S04P } 2011}$} \\
\hline Layer 1 & -311.41 & -1.64 & 115.87 & 0.54 & 27.17 & -55.15 & 174 & 3.4 \\
\hline Layer 2 & 790.14 & -1.49 & 79.70 & 0.44 & 57.17 & -52.24 & 1247 & 2.3 \\
\hline Layer 3 & -5101.86 & 11.00 & 157.30 & 0.32 & -12.24 & 66.83 & 664 & 1.6 \\
\hline Layer 4 & 4271.66 & -93.40 & 389.67 & 0.25 & -6.93 & -549.41 & 206 & 1.3 \\
\hline Layer 5 & -650.82 & -34.75 & 254.71 & 0.16 & -14.55 & -208.99 & 135 & 1.3 \\
\hline \multicolumn{9}{|c|}{ S04P 1992} \\
\hline Layer 1 & -390.66 & -1.93 & 106.09 & 0.67 & 44.05 & -42.16 & 219 & 3.5 \\
\hline Layer 2 & 545.18 & -1.42 & 101.21 & 0.51 & 53.75 & -70.19 & 928 & 2.7 \\
\hline Layer 3 & -6630.17 & -6.96 & 281.25 & 0.31 & 5.20 & -32.51 & 475 & 2.0 \\
\hline Layer 4 & -2301.19 & 119.49 & -367.44 & 0.20 & -37.87 & 613.74 & 162 & 1.5 \\
\hline Layer 5 & -1420.92 & -75.96 & 414.96 & 0.24 & 23.36 & -381.65 & 220 & 1.7 \\
\hline \multicolumn{9}{|c|}{ P16S 2011} \\
\hline Layer 1 & 12681.98 & 132.22 & -2778.47 & 0.15 & 15.20 & 3049.38 & 17 & 3.6 \\
\hline Layer 2 & 2165.41 & 7.66 & 16.37 & 0.52 & 29.49 & -21.43 & 129 & 3.3 \\
\hline Layer 3 & -27224.26 & -190.12 & 1614.65 & 0.10 & -27.46 & -936.03 & 90 & 1.7 \\
\hline Layer 4 & 149098.00 & 2457.97 & -14272.66 & -0.87 & -110.17 & 12322.56 & 18 & 0.6 \\
\hline Layer 5 & 64633.17 & 701.28 & -4721.91 & 0.14 & 24.79 & 3582.65 & 47 & 1.8 \\
\hline \multicolumn{9}{|c|}{ P16S 2005} \\
\hline Layer 1 & 1493.39 & 6.52 & -244.94 & 0.44 & 91.90 & 320.12 & 25 & 2.6 \\
\hline Layer 2 & 1454.31 & 0.87 & 69.45 & 0.55 & 42.44 & -62.59 & 98 & 1.6 \\
\hline Layer 3 & -596.36 & 23.57 & 5.48 & 0.37 & -12.32 & 93.46 & 65 & 0.6 \\
\hline Layer 4 & -6176.18 & -198.98 & 1095.73 & 0.26 & -5.81 & -1045.97 & 19 & 0.7 \\
\hline Layer 5 & 12970.37 & -70.97 & -80.95 & 0.58 & -13.37 & -280.73 & 53 & 0.6 \\
\hline
\end{tabular}

${ }^{\mathrm{a}}$ where $n$ is the number of observations in each fit

Layer 1: $\gamma^{\mathrm{n}} \leq 27.75 \mathrm{~kg} \mathrm{~m}^{-3}$

Layer 2: $27.75 \mathrm{~kg} \mathrm{~m}^{-3}<\gamma^{\mathrm{n}} \leq 28.15 \mathrm{~kg} \mathrm{~m}^{-3}$

Layer 3: $28.15 \mathrm{~kg} \mathrm{~m}^{-3}<\gamma^{\mathrm{n}} \leq 28.27 \mathrm{~kg} \mathrm{~m}^{-3}$

Layer 4: $28.27 \mathrm{~kg} \mathrm{~m}^{-3}<\gamma^{\mathrm{n}} \leq 28.3 \mathrm{~kg} \mathrm{~m}^{-3}$

Layer 5: $\gamma^{\mathrm{n}}>28.3 \mathrm{~kg} \mathrm{~m}^{-3}$ 
Table 4. AOU MLR fit coefficients

\begin{tabular}{|c|c|c|c|c|c|c|c|c|}
\hline \multicolumn{9}{|c|}{ MLR fit equation: $A O U=a+b(S)+c(\Theta)+d\left(\gamma^{n}\right)+e(P)+f(S i)$} \\
\hline \multicolumn{8}{|c|}{ Cruise } & \multirow{2}{*}{$\begin{array}{r}\text { std. error } \\
\mu \mathrm{mol} \mathrm{kg}\end{array}$} \\
\hline$\gamma^{\mathrm{n}}$ layer & $a$ & $b$ & $c$ & $d$ & $e$ & $f$ & $n^{a}$ & \\
\hline \multicolumn{9}{|c|}{ S04P 2011} \\
\hline Layer 1 & -3363.09 & -16.82 & 419.59 & 0.70 & 49.25 & -398.91 & 174 & 8.5 \\
\hline Layer 2 & -2401.05 & -9.79 & 230.29 & 0.42 & 97.37 & -202.61 & 1247 & 2.5 \\
\hline Layer 3 & -6230.21 & -8.50 & 277.32 & 0.29 & 8.53 & -117.18 & 664 & 0.8 \\
\hline Layer 4 & -4144.54 & -5.26 & 211.94 & 0.16 & 2.49 & -109.62 & 206 & 0.5 \\
\hline Layer 5 & -6322.14 & 20.25 & 142.94 & 0.12 & 1.18 & 52.18 & 135 & 0.5 \\
\hline \multicolumn{9}{|c|}{ S04P 1992} \\
\hline Layer 1 & -1706.38 & 0.52 & 160.01 & 1.54 & 50.31 & -140.37 & 219 & 6.0 \\
\hline Layer 2 & -3284.89 & -7.39 & 244.52 & 0.36 & 94.57 & -188.51 & 928 & 2.7 \\
\hline Layer 3 & -3338.19 & -7.97 & 188.85 & 0.18 & 29.57 & -112.08 & 475 & 0.6 \\
\hline Layer 4 & 1275.05 & 51.18 & -178.53 & 0.20 & 8.12 & 176.91 & 162 & 0.4 \\
\hline Layer 5 & -536.625 & 38.97 & -75.88 & 0.16 & 7.52 & 115.29 & 220 & 0.3 \\
\hline \multicolumn{9}{|c|}{ P16S 2011} \\
\hline Layer 1 & -338.46 & 47.47 & -800.04 & 0.07 & 20.41 & 1000.95 & 17 & 1.3 \\
\hline Layer 2 & -228.63 & 7.09 & 112.51 & 0.56 & 77.12 & -134.02 & 129 & 2.9 \\
\hline Layer 3 & 12261.66 & 135.14 & -851.14 & 0.12 & 1.87 & 614.29 & 90 & 0.3 \\
\hline Layer 4 & 6959.95 & 58.97 & -354.93 & 0.19 & 7.29 & 192.46 & 18 & 0.1 \\
\hline Layer 5 & 15196.00 & 258.30 & -1480.67 & 0.20 & 9.12 & 1281.43 & 47 & 0.1 \\
\hline \multicolumn{9}{|c|}{ P16S 2005} \\
\hline Layer 1 & 211.66 & 15.98 & -372.04 & 0.48 & 132.84 & 443.40 & 25 & 6.9 \\
\hline Layer 2 & -4180.85 & -3.89 & 174.72 & -0.11 & 77.84 & -67.37 & 98 & 2.7 \\
\hline Layer 3 & -475.93 & 28.12 & -65.68 & -0.10 & 2.12 & 102.40 & 65 & 0.1 \\
\hline Layer 4 & 1334.04 & 73.86 & -274.10 & 0.20 & -3.15 & 292.91 & 19 & 0.0 \\
\hline Layer 5 & -2005.29 & -1.58 & 125.71 & 0.23 & -2.19 & -79.48 & 53 & 0.1 \\
\hline
\end{tabular}

${ }^{a}$ where $n$ is the number of observations in each fit

Layer 1: $\gamma^{\mathrm{n}} \leq 27.75 \mathrm{~kg} \mathrm{~m}^{-3}$

Layer 2: $27.75 \mathrm{~kg} \mathrm{~m}^{-3}<\gamma^{\mathrm{n}} \leq 28.15 \mathrm{~kg} \mathrm{~m}^{-3}$

Layer 3: $28.15 \mathrm{~kg} \mathrm{~m}^{-3}<\gamma^{\mathrm{n}} \leq 28.27 \mathrm{~kg} \mathrm{~m}^{-3}$

Layer 4: $28.27 \mathrm{~kg} \mathrm{~m}^{-3}<\gamma^{\mathrm{n}} \leq 28.3 \mathrm{~kg} \mathrm{~m}^{-3}$

Layer 5: $\gamma^{\mathrm{n}}>28.3 \mathrm{~kg} \mathrm{~m}^{-3}$ 
Table 5. Anthropogenic Carbon Storage Rate Comparison

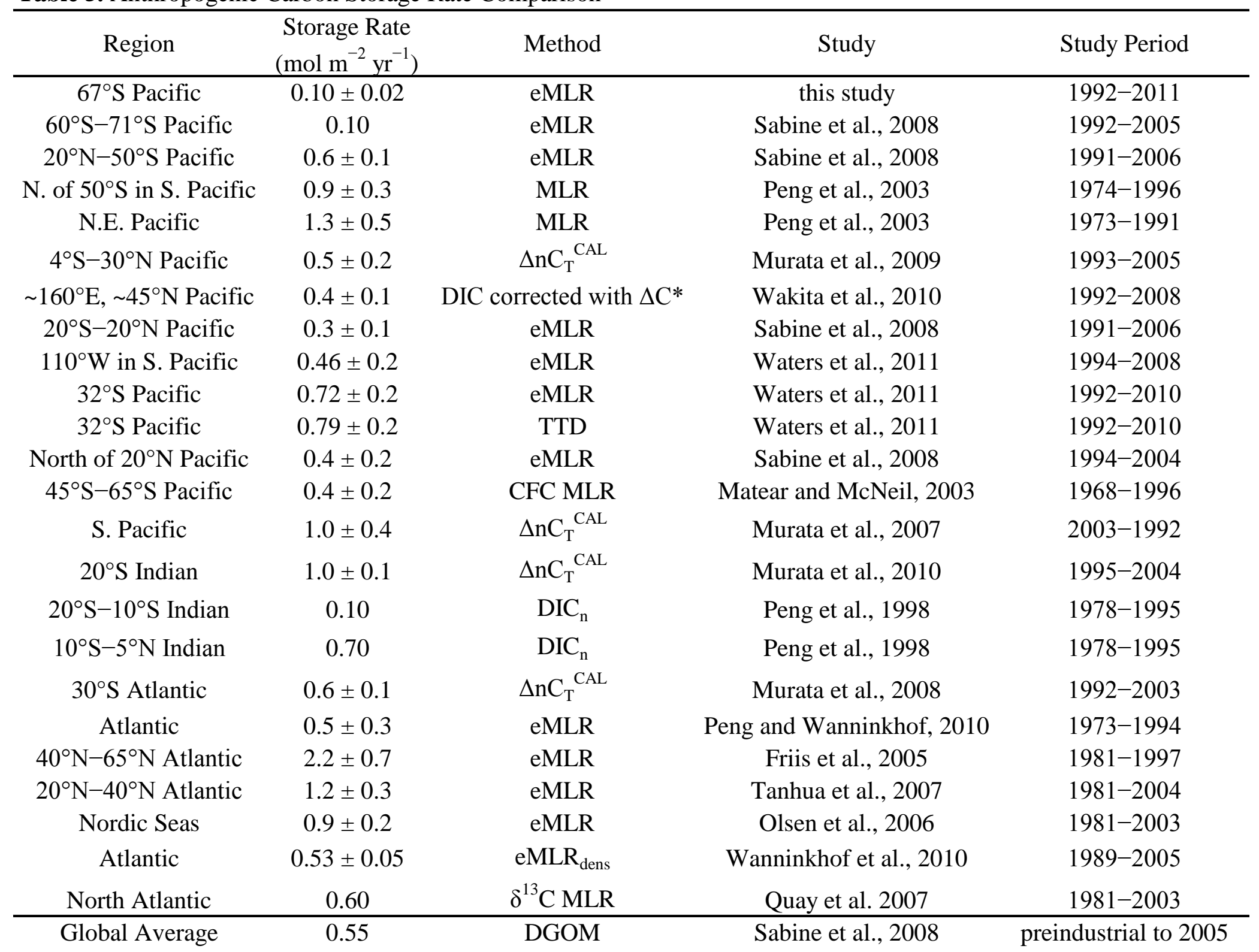


Table 6: Comparison of $\mathrm{pH}$ changes and Aragonite Saturation changes in surface waters

\begin{tabular}{|c|c|c|c|c|c|}
\hline Region & $\begin{array}{c}\text { pH Change } \\
\left(\mathrm{pH} \text { units } \mathrm{yr}^{-1}\right)\end{array}$ & $\begin{array}{c}\Omega_{\text {Aragonite }} \text { Shoaling } \\
\left(\mathrm{m} \mathrm{yr}^{-1}\right)\end{array}$ & $\begin{array}{c}\Omega_{\text {Aragonite }} \text { Change } \\
\left(\% \mathrm{yr}^{-1}\right)\end{array}$ & Study & Study Period \\
\hline Pacific Southern Ocean (S4P) & $-0.0022 \pm 0.0004$ & $2.0 \pm 0.7(\Omega=1.3)$ & $-0.47 \pm 0.10$ & this study & $1992-2011$ \\
\hline Polar Zone Southern Ocean & $-0.0020 \pm 0.0003$ & & & Midorikawa et al, 2012 & $1963-2003$ \\
\hline Drake $(\mathrm{PZ})$ & $-0.0015 \pm 0.0008$ & & $-0.46 \pm 0.4$ & Takahashi et al., 2014 & $2002-2012$ \\
\hline Drake (SAZ) & $-0.0023 \pm 0.0007$ & & $-0.69 \pm 0.4$ & Takahashi et al., 2014 & $2002-2012$ \\
\hline S. Pacific & & $1.9 \pm 0.8(\Omega=1.0)$ & $-0.35 \pm 0.05$ & Feely et al., 2012 & $1991-2005$ \\
\hline S. Pacific & -0.0016 & & & Waters et al., 2011 & 1994-2008 \\
\hline N.W. Pacific & $-0.0015 \pm 0.005$ & & & Midorikawa et al., 2010 & $1983-2007$ \\
\hline N.W. Pacific & -0.002 & & -0.34 & Ishii et al., 2011 & 1994-2008 \\
\hline N. Pacific & -0.0017 & & & Byrne et al., 2010 & $1991-2006$ \\
\hline Iceland Sea & $-0.0023 \pm 0.0003$ & $4(\Omega=1.0)$ & $-0.48 \pm 0.07$ & Olafsson et al., 2009 & $1985-2008$ \\
\hline Irminger Sea & $-0.0026 \pm 0.0006$ & & $-0.40 \pm 0.20$ & Bates et al., 2014 & $1983-2012$ \\
\hline N. Atlantic (BATS) & $-0.0017 \pm 0.0001$ & & $-0.26 \pm 0.02$ & Bates et al., 2014 & $1983-2012$ \\
\hline N. Atlantic (BATS) & $-0.0018 \pm 0.0002$ & & $-0.34 \pm 0.03$ & Takahashi et al., 2014 & $1983-2010$ \\
\hline N. Atlantic (ESTOC) & $-0.0018 \pm 0.0002$ & & $-0.34 \pm 0.07$ & Bates et al., 2014 & 1995-2012 \\
\hline N. Atlantic (ESTOC) & $-0.0017 \pm 0.0001$ & & -0.36 & González-Dávila et al., 2010 & 1995-2004 \\
\hline N. Atlantic (ESTOC) & $-0.0020 \pm 0.0004$ & & $-0.29 \pm 0.06$ & Takahashi et al., 2014 & $1996-2010$ \\
\hline Carribbean (CARIACO) & $-0.0025 \pm 0.0004$ & & $-0.18 \pm 0.08$ & Bates et al., 2014 & 1995-2012 \\
\hline E. Equatorial Indian & $-0.0016 \pm 0.0001$ & & $-0.25 \pm 0.01$ & Xue et al., 2014 & $1962-2012$ \\
\hline
\end{tabular}

